\title{
COMMENTS
}

\section{NATIONAL REPRESENTATION FOR THE DISTRICT OF COLUMBIA: A LEGISLATIVE SOLUTION}

\section{LAWRENCE M. FRANKEL†}

At a time when representative democracy is spreading across the globe, it seems ironic that the capital of the "free world" is a city in which over 600,000 residents have no effective voice in the national government that rules over them. In spite of the fact that the residents of the city of Washington in the District of Columbia are United States citizens, pay federal taxes, and are under the direct control of the national government, they are deprived of the right to vote for representatives in Congress and are thus, effectively disenfranchised. ${ }^{1}$ Despite dozens of proposals and a tremendous amount of debate, the American citizens who are geographically closest to the heart of federal power remain politically furthest from it, as they have been for the past 190 years.

The media's focus on the District of Columbia's recent drive for statehood has attracted national attention to the issue of representation for the District. ${ }^{2}$ Statehood bills have been introduced in Congress." In November 1990, the District elected two "shadow

† B.A. 1988, Cornell University; M.A. in Public Policy \& Management 1991, The Wharton School, University of Pennsylvania; J.D. Candidate 1992, University of Pennsylvania. I would like to thank Professor Ed Baker for his thoughtful suggestions on early drafts of this Comment.

1 The District does have one non-voting delegate in the House of Representatives. See 2 U.S.C. \$ 25(a) (1988). However, this does not provide District residents with an effective voice equal to (or even remotely close to) that of U.S. citizens in the other fifty states who elect two voting senators and one voting representative to the national legislature.

2 See, e.g., Mashek, Another Uphill Battle for Jackson: D.C. Statehood, Boston Globe, June 10, 1991, Nation section, at 3, col. 1; Rally, Forum to Urge Statehood, Wash. Times, May 17, 1991, at B2; Wilgoren, Norton Plans to Propose D.C. Statehood Legislation, Wash. Post, May 15, 1991, at C3, col. 1; Nichols, Statehood Backer Withholds Tax, USA Today, April 16, 1991, at 2A, col. 4.

${ }^{3}$ See, e.g., Gannett News Service, Mar. 9, 1990 (LEXIS, Nexis library, Omni file) (stating that Delegate Fauntroy and Sen. Kennedy had introduced similar statehood bills); 136 CoNG. REC. S6466 (daily ed. Jun. 17, 1990) (statement of Sen. Kennedy introducing statehood bill); 133 CoNG. REG. S3964 (daily ed. Mar. 26, 1987) (same); 133 CoNG. REC. H1410 (daily ed. Mar. 17, 1987) (statement of Delegate Fauntroy introducing statehood bill). 
senators" to pressure Congress for statehood. ${ }^{4}$ This recent initiative is only the latest in a series of attempts by District residents, and their supporters, to gain representation. ${ }^{5}$ Despite these efforts, it appears that the drive for D.C. statehood is unlikely to succeed in the near future. Neither house of Congress has approved a statehood bill, and given the vehement opposition of some representatives and senators, particularly Republicans, ${ }^{6}$ it is unlikely that either house will approve such a bill. Although resistance to District statehood is largely political in nature, opposition also stems from constitutional and "public policy" concerns. ${ }^{7}$ Foremost among these concerns is that statehood would eliminate a separate federal district under exclusive congressional jurisdiction. Such a district is perceived as either constitutionally required, ${ }^{8}$ or is thought of, by Congress and the American public, as highly desirable for historical, traditional, and practical reasons. ${ }^{9}$

${ }^{4}$ See Harvey, Statehood Lobbyis's to Climb Hill With Nothing From City in Pockets, Wash. Times, Nov. 8, 1990, at B6, col. 1. The two elected "shadow senators" are Jesse Jackson and Florence Pendleton. In addition, a "shadow" House representative, Charles Moreland, was also elected. See id. This "shadow" delegation has no real power and has been granted virtually no resources to accomplish its assigned task of lobbying Congress for D.C. statehood. The District is providing them with no money for salary or staff and, of course, they have no vote in Congress. However, in electing "shadow senators," the District is attempting to follow in the footsteps of six other territories which elected "shadow senators" prior to achieving statehood. See id.

${ }^{5}$ See infra note 28 and accompanying text.

${ }^{6}$ See, e.g., 136 CoNG. REC. H404 (daily ed. Feb. 21, 1990) ("If the District wants to have two senators, then let it go back to Maryland where it came from.") (comment of Rep. McEwen, (R)). Given the demographic makeup of the District and its tendency to vote overwhelmingly Democratic in Presidential elections, Republicans in Congress undoubtedly fear that any representatives or senators from the District would be Democrats and further add to that party's majority in both Houses. See Devroy \& Melton, President Opposes Statehood, Wash. Post, Mar. 24, 1990, at A1, col. 1, A22, col. 3 (relating statement of Republican Party strategist Ed Rollins that "Republicans do not fayor statehood for the District [because] you're going to get two liberal Democrats [in the Senate] and keep getting them for the next 100 years ${ }^{\prime}$ ); D.C. Statehood Backed, Chicago Tribune, June 4, 1987, at 20, col.1 (noting that all four Republicans in a House Committee voted against a statehood bill). The allegation is often made that opposition to representation for the District is based on the "four toos": the District is "too liberal, too urban, too black or too Democratic." 124 CONG. REC. 26,345 (1978) (statement of Sen. Kennedy); see also Jackson, The Case for America's 51st State-New Columbia, Chicago Tribune, June 18, 1990, at 11, col. 2 (reviewing the "four toos").

${ }^{7}$ See infra notes 54-63 and accompanying text (discussing the arguments against statehood).

8 This constitutional argument is based primarily on the "exclusive jurisdiction" clause in article $I$, section 8 , clause 17 and on the twenty third amendment. See U.S. CoNsT. art. I, $\$ 8, \mathrm{cl} .17$; id. amend. XXIII. The argument is discussed in detail below. See infra notes $44-47$ and accompanying text.

${ }^{9}$ See infra notes $48,104-07$ and accompanying text (discussing reasons for 
Although lack of national representation for the District is a critical problem and a major flaw in our democratic system, statehood may not be thought an acceptable solution.

This Comment proposes an alternative solution to the problem of District disenfranchisement, one which is more politically feasible, does not eliminate the separate federal city under exclusive congressional jurisdiction, and is more within the spirit and intent of the Constitution than is statehood. Under this solution Congress can, and should, pass legislation granting the District two senators and one representative in Congress; in effect, Congress should pass a law requiring that the District be treated as a state for purposes of representation. A variant of this solution was attempted in 1978 when Congress approved a constitutional amendment which would have given the District two senators and a representative, however, the amendment was never ratified. ${ }^{10}$

It has usually been assumed that a constitutional amendment would be necessary for the District to receive its own congressional representatives. ${ }^{11}$ This Comment challenges that assumption and suggests that the conventional argument upon which it is basedthat article $I$ and the seventeenth amendment prohibit District representation on the basis that it is not a "state" and only "states" can have congressional representation-is without merit. ${ }^{12}$ Fur-

maintaining a separate federal district, including the desire to avoid a state government having influence, or the appearance of influence, over a federal government located within its midst).

10 The amendment died when only sixteen states ratified it. Thirty-eight were necessary for the amendment to succeed. See S. MARKMAN, STATEHOOD FOR THE District of COlUMBIA 3 n.1 (1988).

11 See Franchino, The Constitutionality of Home Rule and National Representation for the District of Columbia, 46 GEO. L.J. 377, $407-08$ (1958) ("It would appear that constitutional amendment is the sole method of providing national franchise for District citizens, and the proposals have been in that form." (footnote omitted)). The 1978 proposed amendment continued the pattern of congressional attempts to correct the problem of District disenfranchisement by amendment. If Congress thought the District could be granted congressional representation through legislation, it would have, at some point, attempted this, rather than consistently pursuing the more difficult process of constitutional amendment. The one notable exception to the assumption that constitutional amendment is necessary to provide the District with representation is Raven-Hansen, Congressional Representation for the District of Columbia: A Constitutional Analysis, 12 HARV. J. ON LEGIS. 167 (1975), which challenged "the hitherto unchallenged assumption that the Constitution denies citizens of the District representation" and suggested that the District might already be treated as a state, presumably by judicial action. Id. at 168. Raven-Hansen's article is discussed further below at infra note 101 .

12 See U.S. CONST. art. I, \$ 2; id. amend. XVII. This argument is discussed (and the relevant clauses are quoted) below. See infra notes 64-66 and accompanying text. 
thermore, it is argued that several provisions of the Constitution suggest that Congress should be permitted to treat the District as a state for purposes of representation. In particular, the longstanding denial of representation to the citizens of the District appears to constitute due process and equal protection violations which Congress has the constitutional power to remedy by enacting appropriate legislation. A legislative grant of representation to the District would be entirely consistent with the spirit and letter of the Constitution and would remedy a wrong that has gone uncorrected for almost two centuries.

Part I of this Comment focuses on the problem of lack of national representation for the District of Columbia. Section IA examines the current situation, how it has come about, and why it is unacceptable. Section IB provides an overview of the proposed solutions to the problem-including statehood-and illustrates why each is unsatisfactory. Part II then elaborates on the solution advocated by this Comment: a legislative grant of congressional representation to the District. Section IIA examines the advantages of this solution. Section IIB argues that, contrary to conventional belief, this solution is constitutional. Section IIB is further subdivided into two parts which attempt to show that: (1) "state" is an inherently flexible concept, not defined in the Constitution and varying in meaning depending on the context, and (2) Congress has the constitutional power to treat the District as a state for purposes of representation. ${ }^{13}$ Finally, section IIC addresses other constitutional and policy challenges to the legislative solution; each is found to be unpersuasive. In short, the legislative solution is not only constitutional, but also far more appealing, from both a constitutional and political perspective, than any other approach to the problem.

13 The conventional way to approach most constitutional issues is to first show that Congress has the constitutional power and then that there is no constitutional provision prohibiting congressional action. However, in this case, in order to obtain a better understanding of congressional power (particularly with regard to defining "states") it is useful to first look at the possible prohibition on congressional action which results from the constitutional provisions regarding "states." 


\section{Stating the Problem ANd Assessing Proposed Solutions}

\section{A. The Status Quo: What It Is, How It Has Come About, and Why It Is Unacceptable}

Article I, section 8, clause 17 of the United States Constitution gives Congress the power " $[t]$ o exercise exclusive Legislation in all Cases whatsoever, over such District (not exceeding ten Miles square) as may, by Cession of particular State, and the Acceptance of Congress, become the Seat of the Government of the United States." 14 In accordance with this provision, Maryland and Virginia both ceded land to the U.S. government; the cessions were accepted by Congress in July of $1790 .{ }^{15}$ On the first Monday in December 1800, the District became the official seat of the national government and on that date, the citizens of the District became disenfranchised-a situation that persists to the current day. ${ }^{16}$

The District of Columbia is a distinct political entity. Its population of approximately 630,000 residents exceeds that of three states. ${ }^{17}$ The vast majority of the District's residents are United States citizens who pay federal taxes. These taxes are, in per capita terms, more than the national average and in absolute terms, greater than the total taxes paid by the residents of eight states. ${ }^{18}$ District residents have served, and continue to serve, in the military with distinction. ${ }^{19}$ Residents of the District are subject to federal

14 U.S. CONST. art. I, $\S 8, \mathrm{cl}$. 17. This clause is usually referred to as either the "exclusive legislation" or "exclusive jurisdiction" clause.

${ }^{15}$ See Raven-Hansen, supra note 11, at 173. The Virginia portion was "retroceded" back to that state in 1846. See Franchino, supra note 11, at $378-82$ (describing the history of the Virginia retrocession).

16 See Raven-Hansen, supra note 11, at 174.

17 Alaska, Wyoming, and Vermont all have a smaller population than the District. See THE WORLD ALMANAC 540 (M. Hoffman ed. 1989). Of course, the numbers involved are not the real problem. The problem of a defined class of citizens being deprived of a voice in national affairs on the basis of geography would exist even if the population of the District was smaller than each and every state's. See J. BEST, NATIONAL REPRESENTATION FOR THE DISTRICT OF COLUMBIA 4-5 (1984) ("Issues of fundamental justice should not turn on the numbers of the people involved.").

${ }^{18}$ See Jackson, supra note 6 , at 11 , col. 3. In 1989, District residents paid $\$ 1.38$ billion in federal taxes. Per capita, this figure was $\$ 500$ above the national average-a fact which should not be surprising when it is noted that per capita income for District residents is well above the national average. See id. Again, however, numbers are not what is critical. "The amount of taxes paid-whether it be greater or smaller than any or all of the states-is irrelevant. It is the fact of paying taxes without representation in the taxing body that is relevant." J. BEST, supra note 17, at 5 .

${ }^{19}$ See 124 CONG. REC. 26,346 (daily ed. Aug. 16, 1978) (statement of Sen. Kennedy pointing out that the casualty level in the Vietnam War was higher for 
laws. In short, residents of the District have the same responsibilities as the residents of any state in the nation and yet simply because of geography and historical accident, ${ }^{20}$ they are controlled by a national government in which they have no effective representation. Despite general recognition of this problem and vocal support for a solution among members of Congress, as well as academic commentators, ${ }^{21}$ concern about the issue has not been sufficient to translate a proposed solution into reality.

There are a number of problems associated with lack of representation for the District, the combination of which make the status quo unacceptable. The most basic problem, clearly reflected in the arguments of many advocates of D.C. representation, is the "fairness problem": it is fundamentally unfair and unjust for several hundred thousand full-fledged, tax-paying American citizens to have no voice in running the national government. ${ }^{22}$ It should strike one as hypocritical that a government which adds vocal and economic support to movements for representative democracy abroad is centered in a city whose citizens are shut out from representative democracy at the national level.

residents of the District than that for ten states).

${ }^{20}$ As explained below, disenfranchisement of District residents was not intentional, but rather was the unfortunate result of the founding fathers' establishment of an area of exclusive federal control while inadvertently failing to provide for direct national representation for the area. See infra notes 103-15 and accompanying text.

${ }^{21}$ See, e.g., J. BEST, supra note 17, at 2-10 (describing the case for national representation); Franchino, supra note 11, at 377 (stating that "basic American political theory supports national and local franchise for District citizens"); RavenHansen, supra note 11, at 167 ("At the end of a decade marked by congressional and judicial activism in extending the franchise, it seems to many ironic that Congress and the Supreme Court should sit amidst several hundred thousand American citizens who are denied representation in the national legislature."); 124 CONG. REC. 26,344 (1978) (statement of Sen. Kennedy that District disenfranchisement ${ }^{\text {is an anachro- }}$ nism that defies justice and denies one of the basic and most cherished rights of representative government for the people of the Nation's capital ${ }^{\text {) }}$; id. at 26,375 (statement of Sen. Hatch, an opponent of most actual attempts to enfranchise the District, that he believes "they should have voting rights in the District").

${ }^{22}$ See, e.g., 124 CONG. REC. 26,369 (1978) (statement of Sen. Thurmond that he favors representation because "[i]t is just not fair, that ... more than 700,000 American citizens do not have the right to elect representatives to Congress"); Jackson, Foreword: The State of New Columbia-A Call for Justice and Freedom, 39 CATH. U.L. REv. 307, 310 (1990) (referring to the problem of District non-representation as "the primary ... social justice question of our times"); see also supra note 21 (listing statements in support of enfranchisement, several of which express the "fairness" rationale either explicitly or implicitly). 
One corollary to the "fairness issue" is the "taxation without representation" problem. This concept, a rallying cry of the American revolution, appears directly contravened by the fact that District residents must pay federal taxes levied by Congress without being represented in that body. ${ }^{23}$ The disenfranchisement of more than 600,000 District residents is also contrary to basic democratic theory and to the republican form of government established by the Constitution. ${ }^{24}$ Furthermore, the fundamental principle that a just and legitimate government must derive power from the consent of the governed is contradicted in the case of the District, as District residents have clearly signified their dissatisfaction with their lack of representation. ${ }^{25}$

Finally, and perhaps most importantly, the United States Constitution itself suggests that the status quo may be unacceptable. Disenfranchisement of District residents may be a violation of constitutionally guaranteed equal protection and due process rights. ${ }^{26}$ Given the fundamental status of the vote under the Constitution, ${ }^{27}$ complete and permanent deprivation of the franchise to a definable subsection of the U.S. citizenry constitutes a serious problem requiring remedy.

\section{B. Proposed Solutions (and Their Respective Flaws)}

There has been no shortage of solutions proposed to deal with the problem of D.C. disenfranchisement, or for that matter, of resolutions in Congress attempting to remedy the situation. In fact, in the past 190 years, "the movement to provide national representation for the District of Columbia ... [has] produced more than

23 See Franchino, supra note 11, at 378 ("It has been argued with great force that the principle of 'no taxation without representation' is such a basic tenet of American political philosophy that it imposes a mandate upon Congress to afford representation to District citizens.").

24 See THE Federalist No. 43, at 274 (J. Madison) (C. Rossiter ed. 1961) (describing the confederation established by the Constitution as one "founded on republican principles, and composed of republican members"); id. No. 39, at 241 (defining republican government as one which "derives all its powers directly or indirectly from the great body of the people").

${ }^{23}$ The District has, in fact, passed a referendum calling for statehood. See infra note 76.

26 These guarantees are contained in both the fifth and fourteenth amendments; the apparent violations are discussed below at infra notes 129-53 and accompanying text.

27 See infra notes 137-42 and accompanying text (discussing case law holding that the right to vote is a "fundamental right"). 
150 congressional resolutions. ${ }^{28}$ While the failure of these attempts can largely be attributed to politics, ${ }^{29}$ contributing also to their failure has been legitimate disagreement concerning which solution is most appropriate from a constitutional and public policy standpoint.

For the most part, the proposed solutions fall into one of three general categories: (i) a constitutional amendment granting the District representation while maintaining its status as a "non-state" federal city under exclusive jurisdiction of Congress, (ii) allowing the District to become part of Maryland, either in full or simply for purposes of representation (commonly referred to as "retroces-

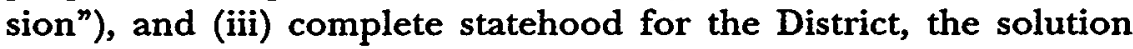
most in the public eye today. Each of these solutions has inherent political and/or constitutional flaws which have prevented implementation.

\section{Constitutional Amendment Granting Congressional Representation}

Congress first considered a constitutional amendment granting national representation to the District in $1888 .{ }^{30}$ Since then, numerous other amendments have been proposed, varying not only in form but also in the number and type of representatives to be given the District. ${ }^{31}$ In 1978, Congress approved, by the necessary two-thirds vote in both houses, a proposed amendment mandating that the District be considered a state for purposes of representation. ${ }^{32}$ In order to be ratified, the amendment required approval by three-fourths of the state legislatures within the seven year period allotted by Congress. Unfortunately, it never even came close to success. ${ }^{33}$

$28 \mathrm{~J}$. BEST, supra note 17 , at 14.

29 As previously stated, Republicans have a motive to resist enfranchising the District since its congressional delegation would most likely be completely Democratic. See supra note 6. Furthermore, neither Democrats nor Republicans in either the Congress or the state legislatures have any electoral incentive to push for representation for the District since District voters have no power to either vote for or against them.

${ }^{30}$ For the text of this proposed amendment, see Franchino, supra note 11, at 408.

31 For the text of several of these proposals and references to several more, see id. at 408-09 \& nn.74-78.

${ }^{32}$ For a copy of the text of the proposed amendment, see J. BEST, supra note 17, at 25.

${ }^{33}$ See supra note 10. 
Undoubtedly, there were many reasons the amendment failed, probably almost as many as there were states which failed to ratify it. Many of the arguments asserted then against statehood are the same as those asserted now. ${ }^{34}$ In spite of the fact that a constitutional amendment would seem, by its very nature, to obviate any constitutional problems, at least one scholar argued that the proposed amendment was unconstitutional. ${ }^{35}$ Yet, behind the intellectual arguments, there was a very practical political problem which in all likelihood doomed the proposed amendment. While representatives and senators had little to gain electorally from a D.C. representation amendment (and, in fact, this might explain why it took so long for Congress to pass one), the state legislatures considering the amendment had even less incentive to pass one. State legislators never had to answer to District residents for their actions, and never had any real reason to care about an issue which had little to do with running their respective states. In many states, the proposed amendment never even made it to the floor of the legislature. ${ }^{36}$ While it was difficult for District residents to get Congress to recognize their disenfranchisement and to attempt to remedy it, it was practically impossible to get the states to show any concern. Although the Constitution delegates to the federal government many problems which the states are unlikely to have enough concern and political will to remedy, D.C. representation has unfortunately not been thought to be one of these. ${ }^{37}$

${ }^{34}$ See infra notes 54-63 and accompanying text (discussing arguments against statehood).

${ }^{35}$ See J. BEST, supra note 17, at 43-51. Professor Best's book, written in the midst of the ratification battle, is devoted to the thesis that the proposed amendment was unconstitutional, at least in part on the ground that it violated the article $\mathrm{V}$ clause stating that no non-consenting state can be deprived of its equal suffrage in the Senate. Thus, Best claimed, unless all the states consented, the District could not constitutionally receive representation through this amendment. See id. at 43. Since this argument is potentially applicable to the legislative solution advocated by this Comment, as well as to the proposed amendment, it is discussed (and rejected) below. See infra notes $192-95$ and accompanying text.

${ }^{36}$ See J. BEST, supra note 17 , at 1 .

${ }^{37}$ Article III, section 2 of the Constitution gives the federal courts power to adjudicate disputes between citizens of different states mainly to avoid the problem of one state not having enough incentive to treat a citizen of another state fairly. The fourteenth amendment places the protection of certain individual rights in the hands of the federal government due to the post-Civil War fear that some states would not uphold the equal protection and due process rights of all their citizens. Article IV, section 3 gives Congress, rather than the states, the right to admit new states to the Union, presumably at least in part because of the fear that state legislatures might not have sufficient incentive to want to admit new states. In fact, states might deliberately 
What the 1978-1985 amendment effort does suggest, however, is that there was considerable support in Congress (two-thirds in both houses) for resolving the problem of District non-representation by granting the District representation as if it were a state, while preserving exclusive federal jurisdiction over the District. The effort also made clear that were the states entrusted with ratification, they would place provincial concerns (such as dilution of their own congressional representation) over the fundamental individual rights of District residents. Thus, if the federal government wishes to resolve the problem of District representation in a manner it finds satisfactory, it must do so on its own, under a proper exercise of federal power without reliance on the states.

\section{Retrocession}

The second commonly advocated solution for the problem of D.C. representation is that of "retrocession." According to this solution, District residents would vote for a representative in the House and would also be able to vote in the Maryland Senate races. There are many variants of this solution: some call for either all or most of the District to once again become part of Maryland, others call for District residents to simply be considered part of Maryland for voting purposes.

As early as 1803, a bill was introduced in Congress calling for retrocession of the District to Maryland and Virginia to prevent "political slavery. ${ }^{39}$ As recently as 1990, House members introduced bills calling for District residents to vote in Maryland Senate

seek to prevent new states from entering the Union as they would dilute existing congressional representation. (This may also be one reason why the states rejected congressional representation for the District.) The bottom line is that, in general, where the framers thought an issue was one of federal concern and one where the states, due to their more narrow concerns, did not have sufficient incentive to act appropriately, the issue was delegated to the federal government. In fact, the principle reason for establishing a federal district was to provide an area of federal control in which the territory and residents would not be subject to the whims of a particular state or states. See infra notes $104-07$ and accompanying text. Unfortunately, resort to the amendment process to provide for D.C. representation did result in the residents of the federal district, under the exclusive jurisdiction and protection of the federal government, being denied a basic right at the hands of the states.

${ }^{38}$ Retrocession seems to be the favorite solution of some academics. See, e.g., J. BEST, supra note 17, at 77-83 (describing retrocession as the "constitutionally elegant solution"); Franchino, supra note 11, at 413-14 \& n.86 (arguing for partial retrocession and providing a proposed text for a retrocession bill).

${ }^{39}$ See Raven-Hansen, supra note 11, at 177 (citing 12 ANNALS OF CoNG. 499 (1803)). 
races and elect their own representative to the House $\mathrm{H}^{40}$ or, for complete retrocession of the District to Maryland (except for a tiny enclave of federal buildings which would remain under federal control). ${ }^{41}$ This solution is popular, in part, because of a solid historical precedent. In 1846, upon the approval of Congress and the people of Alexandria County (the part of the District originally ceded by Virginia), Alexandria County ceased to be part of the District of Columbia and once again became part of Virginia, thereby restoring to its citizens full voting rights. ${ }^{42}$

Although most people familiar with the situation assume that a constitutional amendment would not be required for retrocession to take place, ${ }^{43}$ there is some debate as to what actually is required. At least one commentator argues that the Constitution now mandates a separate federal district, and thus, full retrocession would require a constitutional amendment since it would eliminate such a district. ${ }^{44}$ Many of the proposals for retrocession may implicitly or explicitly recognize this problem in that they call for the federal government to maintain control over a small enclave of federal buildings. ${ }^{45}$ However, the idea of a federal enclave does not solve the constitutional problems implicated by the twenty-third amendment (which incorporated the District into the presidential election process). ${ }^{46}$ The new, vastly reduced, federal district is likely to have very, very few residents, and yet, under the twentythird amendment, these individuals would still be entitled to three

${ }^{10}$ See Jenkins, Parris Bill Would Let D.C. Vote in Maryland Senate Race, Wash. Post, Mar. 7, 1990, at D1, col. 2.

${ }^{41}$ See 136 CoNG. REC. H646 (daily ed. Mar. 6, 1990) (introduction by Congressman Regula of H.R. 4195).

42 See Franchino, supra note 11, at 378-82.

43 See supra notes $39-41$ and accompanying text (describing attempts at retrocession through legislation); Franchino, supra note 11, at 984-88 (arguing that retrocession by statute would be constitutional).

14 See J. BEST, supra note 17, at 70-71 (arguing that art. I, § 8, cl. 17, (the "exclusive legislation" clause), and the twenty-third amendment (granting the District three electoral votes in presidential elections) give the District a constitutional status which can only be altered by constitutional amendment); see also supra text accompanying note 14 (quoting the language of the "exclusive legislation" clause); infra note 46 (quoting relevant language of the twenty-third amendment).

${ }^{45}$ See, e.g., Franchino, supra note 11, at 414 (recommending that "to avoid the constitutional objections to total retrocession the act should retain a minimum of territory to preserve the identity of the Capital City").

${ }^{16}$ The twenty-third amendment grants to the District " $[a]$ number of electors of President and Vice President equal to the whole number of Senators and Representatives in Congress to which the District would be entitled if it were a State, but in no event more than the least populous State." U.S. CONST. amend. XXIII. 
electoral votes in presidential elections. ${ }^{47}$ This result seems a bit unfair, if not ridiculous.

Regardless of whether retrocession without amendment is constitutional, it does appear that full retrocession, and probably partial retrocession as well, is contrary to the more than twohundred-year-old notion that the United States should have a federal district under exclusive federal jurisdiction and free of the control of any state. Even if many of the original reasons why a separate federal district was originally established are no longer applicable (for instance, it is unlikely that the federal government needs a separate federal district in order to protect itself), and even if retrocession is technically constitutional (although, as discussed above, it may not be), there is a widespread belief that the nation's capital should belong to the nation as a whole and should not be a part of any particular state. ${ }^{48}$ In short, retrocession, even if politically and constitutionally feasible, is not in accordance with tradition, history, and a common intuitive sense of what our capital should be.

Another very substantial problem with retrocession is that many of those most concerned with the problem of D.C. representation are opposed to retrocession. This is evidenced by the fact that District residents have focused their recent energies on statehood, ${ }^{49}$ and when retrocession has been raised as a possibility, it has been met with a rather negative response. ${ }^{50}$ The reasons for

${ }^{17}$ It seems unlikely that the boundaries of the federal enclave could be so drawn to exclude all permanent residents. Not only would the remaining residents have three electoral votes giving them a grossly disproportionate impact on presidential elections, but they would still not have congressional representation. If a federal enclave could somehow be established with no residents, there would be no one to elect the three electoral college representatives as the twenty-third amendment requires. This raises the same constitutionality problem suggested by Professor Best. See supra note 44.

${ }^{48}$ See, e.g., 124 CONG. REC. 26,384 (1978) (statement of Sen. Bayh that "[t]his city belongs to Indiana, to Rhode Island, to Virginia; it belongs to the whole United States of America"); J. BEST, supra note 17, at 65 (stating that a separate federal city is a tradition and traditions "are not to be lightly cast aside").

49 See supra notes $2-4$ and accompanying text.

${ }^{50}$ See, e.g. Jenkins, supra note 40 , at D1, col. 2 (noting opposition to the Parris bill (described supra at note $\mathbf{4 0}$ and accompanying text) from several different sources including the mayor of the District and a member of Congress); Schneider \& Melton, Jackson Chides Schafer for Offer to Annex District, Wash. Post, Feb. 28, 1990, at B5, col. 5 (noting Jesse Jackson's vehement opposition to retrocession); Schrag, The Future of District of Columbia Home Rule, 39 CATH. U.L. REV. 311, 319-20 \& n.53 (1990) (noting that since District residents have approved a statehood initiative, they are likely to be uninterested in retrocession, and reporting a survey of Maryland state legislators 
the opposition to retrocession are fairly obvious. Under retrocession, the District's residents would have a small role in selecting Maryland's two senators (since the population of Maryland dwarfs that of the District), while under other proposed solutions (such as statehood or the 1978 proposed amendment), the District's residents would, themselves, elect two senators, who would be responsible solely to them. Thus, retrocession would give the District much less political power than any of the alternative solutions. The fact that the District has been a distinct political entity, with its own laws and government for almost two hundred years, suggests that its residents have a valid argument when they contend that the problem of non-representation should not be solved in a manner that robs them of their distinct political identity in order artificially to dilute their political influence. Article IV, section 3 of the Constitution supports this reasoning, even if it may not technically be applicable to the District. The clause providing that "[no] State be formed by the Junction of two or more States, or Parts of States, without the Consent of the Legislatures of the States concerned as well as of the Congress, ${ }^{n 1}$ suggests that joining distinct political and geographic entities in order to reduce their political influence and representation in the Senate is contrary to the principles of this republic. Regardless of the strength of these arguments, however, as a practical matter the opposition of the District's residents and political leaders to retrocession make it impractical as a solution to the representation dilemma.

\section{Statehood}

Recently, the solution which has received the most attention, and the most support from advocates of D.C. national representation, has been that of statehood. If the District were to be admitted to the Union as a full-fledged state, it would receive two senators and a number of representatives proportionate to its population (at the moment, one). It is not.entirely clear what would be constitu-

showing overwhelming resistance to the idea of the District rejoining their state); 136 CoNG. REC. S6469 (daily ed. May 17, 1990) (statement of Sen. Kennedy referring to retrocession as an unacceptable "half-hearted initiative[]").

${ }^{51}$ U.S. CONST. art. IV, § 3. As discussed below, the District can and has been treated as a state for certain purposes. See infra notes 84-102 and accompanying text. If the District were to be treated as a state for purposes of this constitutional provision, retrocession would, in fact, be unconstitutional without the consent of both Maryland and the District. 
tionally required for statehood. Yet, the proponents of the idea contend that simple legislation would be sufficient and some, in fact, have introduced such legislation in Congress on a number of occasions. ${ }^{52}$ Despite the recent push, however, statehood legislation has never gotten very far nor is it likely to be passed in the near future. ${ }^{53}$

A wide variety of arguments have been used against the statehood alternative. Some are frivolous, such as the argument that the American flag has no room for a fifty-first star. ${ }^{54}$ Others, although seemingly more substantial, prove to be not much of an obstacle, particularly when weighed against the fundamental right of District residents to enfranchisement and congressional representation. ${ }^{55}$ Several constitutional and public policy objections to statehood, however, do have some merit and may suggest that statehood is not the most appropriate way to enfranchise the District.

Transforming the District into a state would eliminate congressional "exclusive jurisdiction" over the District provided for in article I, section 8 , clause 17 of the Constitution. Since this provision does not absolutely require a federal district, but rather, simply gives Congress power over what "may . . . become the Seat

52 See supra note 3.

${ }^{33}$ The furthest such legislation has gotten is passage in a House Committee. See D.C. Statehood Backed, Chicago Tribune, June 4, 1987, § 1, at 20, col. 1 (reporting that a statehood bill passed the District of Columbia Committee by a vote of six to five).

51 See Dukakis Win Could Help Make Washington D.C. 51 st U.S. State, Reuters, Sept. 7, 1988 (LEXIS, Nexis library, Currnt file).

${ }^{55}$ These include arguments such as the District does not have enough land area to be a state and that the District has too much of a single interest constituency (i.e. federal employees) to be a state. As to the former, nothing in the Constitution or in our basic system of values and traditions places any limit on how big a geographic entity must be to be a state; there is no reason that $600,000 \mathrm{U} . S$. citizens should be deprived of their right to representation because the cumulative area of the land on which they live is smaller than that of the smallest state. Since the latter argument, concerning the District having a single-interest constituency, applies to congressional representation without statehood as well as to the statehood option, it is discussed below. See infra notes 196-97 and accompanying text. These arguments are, for the most part, either explicitly or implicitly political-they reflect the beliefs of their advocates that the residents of the District should not have representation on a par with those of the other states because of the effects that D.C. representation would cause. See, e.g., S. MARKMAN, supra note 10, at xi (foreword by Hal Stratton complaining that " $[t]$ he interests of the constituents of a D.C. senator would require the senator constantly to vote for bigger government, for more taxes, and more intrusions into the States' sphere of authority"); see also supra note 6 (noting that Republicans may fear that the District will consistently elect two Democratic Senators). 
of the Government of the United States, ${ }^{n 56}$ it is unclear whether a legislative act transforming the District into a state (and thereby eliminating congressional control over it) would violate this constitutional provision. Certainly the argument can be made that it would. ${ }^{57}$

Somewhat more convincingly, legislatively created statehood might be unconstitutional in that it would nullify the twenty-third amendment. ${ }^{58}$ An argument can be made that a legislative act turning a constitutional provision into "a dead letter" should be considered unconstitutional. ${ }^{59}$

Finally, statehood would violate the terms under which the land, which now constitutes the District, was originally ceded by Maryland to the federal government. ${ }^{60}$ Maryland's consent to statehood would therefore probably be required to avoid a conflict with the constitutional provision requiring that no "State be formed by ... Parts of States without the Consent of the Legislatures of the States concerned. ${ }^{\text {61 }}$

While these arguments might be mooted by a constitutional amendment granting the District statehood, it would appear that such an amendment is a practical impossibility. Intelligent, rational individuals can debate and disagree as to whether or not statehood legislation would be unconstitutional; it is sufficient for purposes of this Comment to suggest that statehood does raise substantial constitutional concerns which severely limit its feasibility as a solution to the problem of D.C. congressional representation.

Even if one could conclude that the statehood alternative passed constitutional muster, it (like retrocession) would eliminate our separate federal district, a result which is undesirable to many members of Congress and the general public, ${ }^{62}$ and which may be undesirable from a public policy standpoint. ${ }^{63}$ This fact, com-

${ }^{56}$ U.S. CoNST. art I, § 8, cl. 17.

37 See J. BEST, supra note 17, at 70 (arguing that "[a]rticle I recognizes a federal district ... . once a federal district comes into existence it has constitutional status").

${ }^{58}$ Statehood legislation would eliminate the "District constituting the seat of Government of the United States" to which the amendment grants electoral votes. For the text of the twenty-third amendment, see supra note 46.

${ }^{59}$ See J. BEST, supra note 17 , at 71.

${ }^{60}$ See id. at 69 (noting that the land was ceded by Maryland for the purpose of establishing a federal district to serve as the seat of the national government and concluding that "if a federal district is to be abandoned, then Maryland has first claim on the territory").

61 U.S. CONST. art. IV, $\$ 3$.

62 See supra note 48 and accompanying text.

${ }^{63}$ See infra notes 104-07 and accompanying text (discussing why elimination of the 
bined with the constitutional problems previously discussed, may explain why statehood legislation has never come close to succeeding in Congress. While partisan political resistance to giving the District two senators also plays a major role, it should be noted that the proposed amendment which would have treated the District as a state for purposes of representation, but maintained its status as a separate federal city under exclusive federal jurisdiction, did receive a two-thirds vote in both Houses of Congress. Thus, because of constitutional concerns, politics, and the desire to maintain a separate federal city, the statehood alternative may never succeed-perhaps rightfully so. Advocates of national representation for the District must look elsewhere for a solution; that solution may be found in congressional legislation which would treat the District as a state for purposes of representation.

\section{The Legislative SOlution: Legislating REPRESENTATION FOR THE DISTRICT}

The overwhelming congressional approval of the 1978 amendment which would have treated the District of Columbia as a state for purposes of representation suggests that if Congress could cause the District to be treated in this manner without needing to secure the approval of the state legislatures, it would probably do so. It is the position of this Comment that Congress can constitutionally do this, and thereby implement its preferred solution to the problems of District disenfranchisement.

Under the powers granted to it by the Constitution, particularly those granted in the enforcement provisions of the Civil War amendments, Congress can simply legislate congressional representation for the District. By doing so, Congress would correct a twohundred-year-old injustice in a manner that is in accordance not only with the letter and spirit of the Constitution, but also with our traditions and beliefs regarding a separate federal District.

\section{A. Advantages of the Legislative Approach}

If one assumes that legislation treating the District as a state for purposes of congressional representation would be constitutional (and much of the rest of this Comment will be devoted to showing that this is indeed the case), this approach has many advantages

separate federal district is undesirable, even if it would be constitutional). 
which make it superior to both retrocession and statehood. Legislation granting the District a representative in the House and two senators would not only provide effective representation, and thereby solve the problem of disenfranchisement, but also would preserve the District's separate and independent political status. In this sense, this solution is very similar to statehood and vastly superior to retrocession. Furthermore, since the legislative solution would not eliminate a separate federal district and exclusive federal jurisdiction over such District (as would statehood or retrocession), it eliminates any constitutional problem in this regard. In addition, by preserving the District as "a federal city," this solution is much more in accordance with our traditions and history, and thus, more acceptable to the people of the United States and their congressional representatives.

One final and very significant point is that while statehood appears to have little chance of success in Congress, and while retrocession is unacceptable to most District residents, legislation granting representation to the District has an excellent chance of political success. In 1978 Congress showed, by two-thirds vote in both Houses, overwhelming support for the idea that the District should receive congressional representation while remaining under exclusive federal control. It is therefore fairly likely that a simple majority in both Houses could be found to approve legislation achieving the same result. All that would then be necessary for the legislation to become effective would be a presidential signature or the override of a veto. Thus, achieving representation through congressional legislation is not only the best solution for a variety of practical, historical, and constitutional reasons, but it is also the only solution with a real chance of political success in the near future.

\section{B. The Constitutionality of Representation Through Legislation}

If the legislative solution to District disenfranchisement is so superior to other approaches, why has it not been attempted or even seriously discussed? The principal reason is a widespread assumption that Congress lacks the constitutional power to effectuate the legislative alternative. Since it is usually assumed that congressional representation for the District would violate constitutional provisions granting representation in Congress to the states, it is also assumed that only a constitutional amendment, such as the 
one proposed in 1978, could grant representation to the District while maintaining its status as a separate "federal city. ${ }^{\text {"64 }}$

The argument against representation through legislation is based primarily on article I, section 2 which provides, in part that, "[t]he House of Representatives shall be composed of Members chosen every second Year by the People of the several States ${ }^{765}$ and on the seventeenth amendment, which provides in part that "[ $t]$ he Senate of the United States shall be composed of two Senators from each State. ${ }^{\text {66 }}$ The argument asserts that these provisions restrict congressional representation to the "states" and the District is not a "state." Therefore, the District is not entitled to representation and any attempt to provide it, short of constitutional amendment, would be unconstitutional. Although on its face this argument has some plausibility, it is ultimately without merit; there is strong support for the position that legislation granting representation to the District would be constitutional, given the flexibility of the meaning of "state" and the considerable powers granted to Congress by the Constitution.

\section{1. "State" Does Not Necessarily Have To Be Read As Excluding the District in All Contexts}

The determination of whether the Constitution actually forbids the District from receiving representation must start with an examination of the relevant constitutional provisions, using the standard tools of statutory and constitutional construction. There is a wide and varied literature on how one should interpret statutory and constitutional provisions and on what factors should be taken into account. The relative weight individuals give to various factors often results in their categorization as "originalists," "textualists," "intentionalists," "non-originalists," etc. ${ }^{67}$ Commentators may agree that the actual text should be given a great amount of weight, but most also agree that additional factors should be taken into account. These additional factors may include the intent of the framers, the overall structure and spirit of the republican form of government established by the Constitution, and perhaps some

64 See supra note 11 and accompanying text.

${ }^{65}$ U.S. CONST. art. I, \& 2.

${ }^{66}$ Id. amend. XVII.

${ }^{67}$ See Brest, The Misconceived Quest for the Original Understanding, 60 B.U.L. REV. 204 (1980) (discussing different approaches to constitutional interpretation and providing a classification scheme). 
"other principles" including equity, fairness, liberty, and democracy. All of these have found their way into Supreme Court opinions in some form at one time or another. As far back as McCulloch v. Maryland, ${ }^{68}$ the Court acknowledged some of these factors that should be taken into account in interpreting the Constitution. In reading "necessary" in the "necessary and proper clause" to mean useful rather than absolutely necessary, the Court commented that "[t]his word ... like others, is used in various senses; and, in its construction, the subject, the context, the intention of the person using them, are all to be taken into view. ${ }^{n 69}$

Using these principles as guidance, the constitutional provisions granting congressional representation to the states may be interpreted to allow representation for the District. The constitutional provisions which supposedly prohibit Congress from legislating representation for the District, ${ }^{70}$ never explicitly state that result. All they say is that Congress is to be composed of representatives from the states. No definition of "state" is given nor does the text stipulate that Congress may only have representatives from the states. Only a very restrictive and strained textualist interpretation of "state," and the constitutional provisions pertaining to the representation of states in Congress, would prohibit the District from gaining congressional representation by statute.

Since the Constitution never defines "state," it is not clear what the term means when it is used in the various provisions of the Constitution. Certainly, when the founders used the term "state," they meant to include at least the thirteen members of the new American Union, each of which was a former colony originally chartered by the British crown, each with its own militia and government. Yet, then, as now, when employed in general usage, the word "state" has a much broader, less concrete, definition."

6817 U.S. (4 Wheat.) 316 (1819).

${ }^{69} \mathrm{Id}$. at 415 .

70 These are, of course, article I, section 2 and the seventeenth amendment, cited supra notes 65-66 and accompanying text.

71 The most basic definition of state is "a distinct political society." See Hepburn v. Ellzey, 6 U.S. (2 Cranch) 444, 451 (1805). The dictionary refers to a "state" as "a body of people living under a single independent government" or "[o]ne of the political and geographic subdivisions of a federated country." AMERICAN HERTTAGE DESR DICTIONARY 908 (1981). Independent nations are often referred to as "states," as are subdivisions of nations (i.e. state of New York, the Punjab state in India, etc.). Generally, when one thinks of a "state," she is thinking of something with borders, a territory, and a government. Yet, it is clear that, in general usage, there is no fixed or concrete definition of state. 
It is not at all obvious which, if any, of the entities which would come under this broader definition of "state" the framers meant permanently to exclude, particularly in cases where an entity otherwise fits into the constitutional framework. Furthermore, it is not clear that "state" was meant to have the same definition in all contexts. ${ }^{72}$

For at least some purposes, it appears that the framers meant to defer to Congress on the question of what should be considered a "state." Since "statehood" could obviously not be something that was limited to former colonies originally chartered by the English crown, the Constitution gave Congress the power to admit new states to the Union. ${ }^{73}$ Although the Constitution gives no clue as to what is required of a particular geographical and political entity for it to become a "state" for purposes of admission to the Union, Congress has at various times enunciated requirements for statehood. When the Northwest Territories were divided into states, Congress required a population of 60,000 for each territory to be admitted. ${ }^{74}$ Since then, the three principle criteria for statehood have been (1) a commitment to democratic principles, (2) resources and population similar in size to existing states, and (3) an expression of desire for statehood by the inhabitants. ${ }^{75}$ Today, each of the states in the Union was either originally a colony or was "admitted" to the Union under principles adopted by Congress. In effect, Congress, not the Constitution, has defined what a "state" is for purposes of admission to the Union; Congress has made the determination as to which entities are to be included within the constitutional term "state," and which are to be excluded.

The District of Columbia, in virtually all respects, resembles the other states of the Union and meets the congressional statehood criteria. It has a democratically elected local government, definable political boundaries, a population greater than three states, a per capita income above the national average, and has indicated its desire to be treated as a state. ${ }^{76}$ It behaves as do the other states,

72 Indeed, the Supreme Court has taken the position that "state" does not always have the same meaning. See infra notes 98-100 and accompanying text.

73 See U.S. CONST. art. IV, \$ 3.

74 See Ordinance of 1787: The Northwest Territorial Government, § 14, art. V., U.S.C.A. (1987).

75 See S. MARKMAN, supra note 10 , at 69 (statement of Sen. Kennedy on introducing a statehood bill to the Senate Committee on Governmental Affairs, March 26, 1987).

${ }^{76}$ See supra notes 17-18 and accompanying text. In November of 1980, District 
performing such functions as issuing driver's licenses and motor vehicle license plates. While the District clearly meets the congressional criteria for statehood, it was never actually "admitted" to the Union, at least partially because it was always part of the Union in every way, serving as the nation's capital for almost 200 years. ${ }^{77}$ In sum, given the lack of a constitutional definition of "state," the broad general definition of the term, the inherent flexibility of the concept of "state," the congressional definition of "state" for purposes of admission (which the District meets), and the fact that the District already acts as a "state" in many ways, it may be contended that the District should already be considered a "state" for all constitutional purposes, including representation. ${ }^{78}$ It is not, however, necessary to go this far, nor does this Comment wish to take such a position. ${ }^{79}$ All that is necessary is to accept that the constitutional definition of a state is not fixed or necessarily the same in all contexts. There is no constitutionally mandated definition of "state" at all; the task of determining what should be included within the term "state" for various purposes has been left to Congress and the courts. Given these facts, it is difficult to see why the text of the Constitution, on its face, precludes the District from receiving representation.

An examination of the case law in this area supports these conclusions. ${ }^{80}$ The question whether the District can be considered a state arises virtually every time a constitutional or statutory provision refers to the "states" or the citizens of the states. The first

residents approved an initiative calling for statehood by a margin of $60 \%$ to $40 \%$. See S. MARKMAN, supra note 10, at 74 (statement of D.C. councilmember Carol Schwartz).

${ }_{77}$ As previously stated, its citizens are U.S. citizens, pay federal taxes, and serve in the military. See supra notes $18-19$ and accompanying text.

${ }^{78}$ In fact, the Supreme Court has often held that the District should be treated as a state for purposes of some constitutional provisions. See infra notes 84-100. See also infra note 101 (noting the position of Peter Raven-Hansen that the District should already be treated as a state for purposes of representation).

${ }^{79}$ Indeed, the District does have a special constitutional status due to the "exclusive legislation" clause, its unique identity as a federal city, and the fact that it was never "admitted" into the Union by Congress. See U.S. CoNST. art. I, § 8, cl. 17. In this respect, it is different from other states such as Pennsylvania or Maryland. The relevance of these differences is, however, open to debate.

${ }^{80}$ It is the position of Peter Raven-Hansen that the case law goes so far as to support "nominal statehood" for the District. See infra note 101. In arriving at this conclusion, Raven-Hansen's article reviews, in some detail, many of the cases mentioned infra notes 81-100 and accompanying text. See Raven-Hansen, supra note 11, at 179-87. Further discussion of some of the cases (reaching the opposite conclusion) may be found in Franchino, supra note 11, at 390-407. 
case to consider whether the District might be considered a state was Hepbum v. Ellzey. ${ }^{81}$ The Supreme Court ruled that the District was not to be considered a "state" for purposes of diversity jurisdiction in federal courts. It did, however, qualify this holding by ruling that any broadening of the jurisdiction of federal courts to include District residents was a "legislative . . . consideration. ${ }^{782}$ Although this case is often cited as the primary support for the proposition that the District is not to be considered a "state" for most constitutional purposes, ${ }^{83}$ even here, by suggesting that Congress could consider the District a "state" for purposes of federal jurisdiction, the Court did recognize that "state" is an inherently flexible term which Congress has the power to define.

The holding in Hepburn was severely limited by several other 19th century cases. In Loughborough $v$. Blake, ${ }^{84}$ the Court ruled that Congress could directly tax the District in proportion to its population despite the fact that the Constitution apportioned taxes in the same manner as representation. "Representatives and direct Taxes shall be apportioned among the several States which may be included within this Union, according to their respective Numbers ....85 Given this constitutional provision and this holding, a strong argument can be made that the constitutional connection between taxation and representation intended by the framers should remain intact: since the District is treated as a "state" for purposes of taxation, the District should be treated as a "state" for purposes of representation as well.

In Callan $v$. Wilson, ${ }^{86}$ a case involving a basic constitutional right, the Court held that residents of the District were entitled to a trial by jury under the sixth amendment even though the amendment, on its face, only refers to states. ${ }^{87}$ Just a year after Callan the Court, in Stoutenburgh $v$. Hennick, ${ }^{88}$ affirmed that Congress could exercise its power to regulate commerce across District

816 U.S. (2 Cranch) 445 (1805).

${ }^{82} I d$. at 453 . The decision also conceded that the District was a ${ }^{\text {distinct political }}$ community." Id. at 452.

${ }^{83}$ See, e.g., S. MARKMAN, supra note 10, at 12-13 (arguing that "[t]he word 'state' as used in Article I may not be interpreted to include the District of Columbia" and that arguments saying it may be "were properly dismissed long ago by Chief Justice Marshall in Hepburn v. Ellzey").

8418 U.S. (5 Wheat.) 317 (1820).

${ }^{85}$ U.S. CONST. art. I, § 2, cl. 3.

86127 U.S. $540(1888)$.

${ }^{87}$ See U.S. CONST. amend. VI.

88129 U.S. 141 (1889). 
borders even though the commerce clause only referred to commerce "among the several states. ${ }^{n 99}$ The following year, in De Geofroy $v$. Riggs, ${ }^{90}$ the Court held that a treaty between the United States and France, allowing Frenchmen to inherit property in the "States of the Union," applied to the District. The Court commented that while "state" might not ordinarily include an "organized municipality" such as the District, "[t]he term is used in general jurisprudence ... as denoting organized political societies with an established government. Within this definition the District of Columbia ... is as much a State as any of those political communities which compose the United States."

The next major case to consider the status of the District came more than a half century later in National Mutual Insurance Co. $v$. Tidewater Transfer Co. ${ }^{92}$ The Court, by a five to four decision, upheld a congressional statute allowing diversity jurisdiction in federal courts for suits between a citizen of the District and a citizen of another state in spite of the fact that article III, section 2 of the Constitution grants power to federal courts only in cases involving citizens of different states. ${ }^{93}$ The decision was complicated by the fact that there was a plurality opinion, joined in by only three justices, a concurring opinion, and two dissenting opinions. ${ }^{94}$ The plurality opinion refused to overrule Hepburn, but asserted that the exclusive federal power over the District granted by article I, section 8, clause 17 gave Congress the authority to permit diversity jurisdiction in federal courts for suits involving residents of the District and another state. This reading allowed Congress to ignore, in effect, the limitation which article III, section 2 seems to provide. Justice Rutledge reached the same result under a different, and seemingly more persuasive analysis, arguing for an outright overruling of Hepburm. ${ }^{95} \mathrm{He}$ argued that the District should be

${ }^{89}$ U.S. CONST. art. I, \$ 8, cl. 3.

90133 U.S. 258 (1890).

91 Id. at 268-69.

92337 U.S. 582 (1949).

93 See id.; see also U.S. CoNST. art. III, \& 2, cl. 1 ("The judicial Power shall extend to ... Controversies between two or more States;-between a State and Citizens of another State;-between Citizens of different States. ...").

${ }^{94}$ The majority opinion was authored by Justice Jackson and joined by Justices Black and Burton. See National Mutual 397 U.S. at 583. The concurrence was written by Justice Rutledge and joined by Justice Murphy. See id. at 604 . The first dissent was authored by Chief Justice Vinson and joined by Justice Douglas. See id. at 626 . The second dissent was written by Justice Frankfurter and joined by Justice Reed. See id. at 646.

${ }^{95}$ Justices Rutledge and Murphy were apparently unimpressed with the fact that 
treated as a "state" for purposes of article III and that the Court should not "write into the Constitution such an unjust and discriminatory exclusion of District citizens from the federal courts, ${ }^{966}$ particularly when the framers of the Constitution never considered the problem of the District, since the District did not exist at the time of the drafting. "Key words like 'state,' 'citizen,' and 'person' do not always and invariably mean the same thing." ultimate importance of this case is that all five Justices concurring in the result agreed that Congress had the power to give the District a status for purposes of federal diversity jurisdiction, which article III explicitly reserved for the states.

Perhaps the best summary of the current state of the case law with respect to the District is found in Justice Brennan's majority opinion in District of Columbia v. Carter. ${ }^{98}$ The Court used legislative history to construe the words "State or Territory" as including the District for one statutory purpose, but not for another. ${ }^{99}$ "Whether the District of Columbia constitutes a 'State or Territory' within the meaning of any particular statutory or constitutional provision depends upon the character and aim of the specific provision involved." 100 It is important to note not only the Court's realization that "state" is an inherently flexible term, but also its willingness to look at the intent of Congress as to whether the District should be considered a "state."

Thus, even though it may not be obvious that the District should already be considered a "state" for purposes of representation (although a case can be made for this point of view ${ }^{101}$ ), it should

the Hepburm opinion was authored by Chief Justice Marshall. "The very brevity of the opinion and its groundings, especially in their ambiguity, show that the master hand which later made his work immortal faltered." Id. at 618 (Rutledge, J., concurring) (footnote omitted).

${ }^{96} \mathrm{Id}$. at 617.

${ }^{97}$ Id. at 623 (footnote omitted).

98409 U.S. 418 (1973).

99 The Court held that the words "State or Territory" did not include the District for purposes of 42 U.S.C. $\S 1983$, but did for purposes of 42 U.S.C. $\S 1982$. See Carter, 409 U.S. at 420-25. In 1979, Congress amended $\$ 1983$ to include the District. See 42 U.S.C. \$ 1983 (1988).

100 Carter, 409 U.S. at 420 .

101 See Raven-Hansen, supra note 11, at 184-87. Professor Raven-Hansen's article, written more than fifteen years ago, raises the possibility that the District should already be treated as a "state" for purposes of representation. However, it seems to assume that the judiciary can and should do this, since it barely mentions Congress or congressional power to pass legislation that would treat the District as a "state." It is, however, extremely unrealistic to believe that a court would do this today, and in 
be clear that the definition of "state" is: (1) not forever fixed; (2) not always exclusive of the District; and (3) subject to interpretation by Congress and the courts. Other considerations must also be taken into account when deciding whether the District should be considered a "state" for a certain purpose, particularly the original intentions of the framers. In addition, any legislative action on the issue, undertaken under appropriate constitutional authority, should be given great, perhaps determinative, weight. In fact, the cases discussed above indicate that where Congress has chosen to treat the District as a state, the courts are willing to accept congressional judgment. ${ }^{102}$

In looking at whether the District should be given congressional representation, it is useful to consider why it was excluded from representation in the first place. If the drafters of the Constitution had a concrete purpose and reason to disenfranchise the District, and clearly expressed their desires, it might well make sense to read "state," and the clauses granting representation to the states, as excluding the District. A look at the historical reasons for the establishment of the District, however, does not evidence any clear intent to disenfranchise the District. ${ }^{103}$ Rather, history seems to suggest that disenfranchisement was an unfortunate by-product of the establishment of an area of exclusive federal jurisdiction to serve as the seat of the federal government.

Virtually all sources agree that one of the predominant influences on the founding fathers with respect to the need for a separate federal district was the Philadelphia revolt of $1783 .{ }^{104}$ The cir-

fact, there may be good reason for it not to do so. See infra note 120.

102 In particular, recall the discussions of Hennick, National Mutual, and Carter where Congress did make a determination on whether to treat the District as a "state." See supra notes $92-100$ and accompanying text. Actually, Congress routinely treats the District as a state for a wide variety of statutory purposes, without it ever being questioned by the courts. See, e.g., 18 U.S.C. \$ 1953(d) (1988) (interstate transportation of wagering paraphernalia); 26 U.S.C. $\$ 6365$ (a) (1988) (collection of state income taxes); 29 U.S.C. $\$ 50$ (1988) (apprentice labor); 42 U.S.C. $\$ 10603$ (d)(1) (1988) (crime victim assistance program); 42 U.S.C. $§ 2000$ e(i) (1988) (civil rightsequal employment opportunity).

${ }^{103}$ Most commentators seem to agree on this point. See, e.g., J. BEST, supra note 17 , at 14 ("The intent of the Founders on national representation for the District is not clear."); Raven-Hansen, supra note 11, at 191 ("The history of article I, section 8 , clause 17 , and of the legislation ceding and establishing the District, suggest that denial of congressional representation to District residents was neither necessary to effect the constitutional purpose nor desired by those involved. $)$.

${ }^{104}$ See, e.g., J. BEST, supra note 17, at 14-15 ("The proximate cause of the provision for a federal district was the Philadelphia Mutiny of 21 June 1783."); S. MARKMAN, 
cumstances of this event are well documented. In June of 1783, Congress, while in session in Philadelphia, was confronted by approximately eighty unpaid, angry Continental Army soldiers. Congress called upon the government of Pennsylvania to provide protection. The state government, however, refused and Congress was forced to adjourn, quietly leave the city, and reconvene at Princeton. ${ }^{105}$ This event convinced the framers of the Constitution of the need for a separate geographic area to serve as the seat of government, if only for its own protection. ${ }^{106}$ However, the purpose behind a separate federal district was probably somewhat broader than simply ensuring the physical protection of the federal government. "The basic concern [was] that the federal government be independent of the states, and that no one state be given more than an equal share of influence over it ..."107 This concern is presumably more applicable in today's situation than is the simple desire to protect Congress from rebellious soldiers. Even though the vastly increased power of the federal government reduces the risk, it is still true that if a state had the federal government located within its midst, it could exert undue influence, or at least have the appearance of such. It is for these reasons that the "exclusive legislation" clause was inserted into the Constitution, and why it is still applicable today.

The need for exclusive federal jurisdiction over the seat of the national government does not, however, necessarily exclude representation in the federal government for the residents of the District. While the intent of the framers to establish an area free of the influences of any state government is clear, what is far less clear is what they intended with respect to representation of the area.

supra note 10, at 47 ("Unquestionably, this incident made a deep impression on the members [of the Continental Congress]."); Raven-Hansen, supra note 11, at 171 ("That the memory of the mutiny scare . . motivated the drafting and acceptance of the 'exclusive legislation' clause was clearly demonstrated in the subsequent ratification debates.").

103 Accounts of this incident may be found in S. MARKMAN, supra note 10, at 4647, and Raven-Hansen, supra note 11, at 169 .

106 The history of the debates over the Constitution, in addition to such sources as The Federalish, provide strong evidence of this. See THE FEDERALIST No. 43, at 272 (J. Madison) (C. Rossiter ed. 1961) (remarking on the "indispensable necessity of complete authority at the seat of government" since without it, "the public authority might be insulted and [the federal government's] proceedings interrupted with impunity"); Raven-Hansen, supra note 11, at 169-72 (citing statements from the ratification debates).

${ }^{107} \mathrm{~S}$. MARKMAN, supra note 10 , at 48 . 
The question of representation does not appear to have seriously arisen until the federal government took up residence in the District in 1800 , well after the Constitution had been drafted and ratified. ${ }^{108}$ The reasons for this are summarized by Peter RavenHansen:

First, given the emphasis on federal police authority at the capital and freedom from dependence on the states, it is unlikely that the representation of future residents in the District occurred to most of the men who considered the "exclusive legislation" power. As long as the geographic location of the District was undecided, representation of the District's residents seemed a trivial question. Second, it was widely assumed that the land-donating states would make appropriate provision in their acts of cession to protect the residents of the ceded land.... Finally, it was assumed that the residents of the District would have acquiesced in the cession to federal authority. ${ }^{109}$

In addition, the District only had about 14,000 residents, ${ }^{110}$ a very small number even by the standards of that era. Given the lack of real debate or discussion concerning District disenfranchisement, and the readily understandable reasons for this inattention, it appears that the framers of the Constitution did not deliberately intend to disenfranchise the District, nor did they have any reason to do so. At most, some probably realized that because of the way in which the government was structured, the District would be disenfranchised. ${ }^{111}$ Perhaps more importantly, there is no indication that the framers explicitly intended Congress to have no power to remedy the situation. By the time the disenfranchisement actually took place, although there were some attempts to correct the problem, ${ }^{112}$ most people, including the Justices of the Supreme Court, were simply willing to explain it away by asserting that the District "voluntarily relinquished the right of representation, and has adopted the whole body of Congress for its legitimate government."113

${ }^{108}$ See Raven-Hansen, supra note 11, at 172.

109 Id. (footnote omitted).

110 See id. at 177.

111 See, e.g., S. MARKMAN, supra note 10, at 46 (asserting that Alexander Hamilton and Thomas Tredwell raised the issue of District disenfranchisement at the New York ratifying convention).

112 See Raven-Hansen, supra note 11, at 175-76 (describing early statements and attempts in Congress to avoid disenfranchisement for the District).

113 Loughborough v. Blake, 18 U.S. (5 Wheat.) 317,324 (1820). This case is discussed supra notes $84-85$ and accompanying text. 
The assumptions underlying the original failure to provide representation for the District and the failure to correct the problem shortly after disenfranchisement took place, were proven false long ago. First, the ceding states did not provide for representation. Second, the District's population has grown to a point where it is larger than several states. Third, most District residents certainly do not voluntarily consent to the lack of congressional representation. ${ }^{114}$ Given these facts, in the absence of an actual intent to disenfranchise the District, it is probably inappropriate to treat the realization of some of the framers that the District would be disenfranchised ${ }^{115}$ as sufficient cause to not treat the District as a "state" for representation purposes. It is certainly incorrect and even unjust to treat this casual realization as an explicit prohibition on legislative action to correct the problem of disenfranchisement, especially when other constitutional authority exists for such action.

What is perhaps more important than the framers' specific intent (or lack of it) with respect to representation of the District, is their general intent in drafting the Constitution. The Constitution was drafted to establish a republican form of government throughout the entire United States. It explicitly guarantees a republican form of government to every state. ${ }^{116}$ Inherent in this notion of republican government was the idea that the citizens of the nation should be active participants in the political process. ${ }^{117}$ Government by the consent of the governed, through their chosen representatives, was a guiding principle. ${ }^{118}$ The principles of justice and liberty were also viewed as essential. ${ }^{119}$ If equality was not an essential component of the Union in 1787, it certainly

114 Thus, even if it is conceded that District disenfranchisement was not a major problem two hundred years ago, it is today. To suggest it is not amounts to a casual dismissal of the fundamental rights of 600,000 American citizens and constitutes an insult not only to those being deprived of a voice in the affairs of their nation, but also to the republican principles upon which this nation was founded.

115 See supra note 111 and accompanying text.

116 See U.S. CONST. art. IV, § 4. It should be noted that the "republican form of government" clause has been held to be a "political question" which is non-justiciable. See Baker v. Carr, 369 U.S. 186, 218-26 (1962); Luther v. Borden, 48 U.S. (7 How.) 1 (1849). Thus, Congress alone has both the power and obligation to ensure a republican form of government throughout the United States.

117 See, e.g., THE FEDERALIST No. 57, at 351 (J. Madison) (C. Rossiter ed. 1961) (emphasizing that " $[t]$ he electors [of the congressional representatives] are to be the great body of the people of the United States").

${ }_{118}$ See, e.g., The Declaration of Independence para. 2 (U.S. 1776).

119 See U.S. CoNST, preamble. 
became one in the years following the Civil War and the adoption of the thirteenth, fourteenth, and fifteenth amendments.

A proper reading of the Constitution must keep these broad purposes of the drafters in mind. Construing the clauses granting congressional representation to the "states" in such a way as to permanently exclude the District from participation in the political process completely thwarts these purposes. Such a reading transforms the Constitution from a document that bestows liberty, democracy, and representative government into one that prohibits it. Given that the text of the Constitution and the specific intent of the drafters with regard to District representation are far from clear, it would be plausible to construe the document as already granting representation to the District. However, as previously mentioned, this result is not necessary for the purposes of this Comment. ${ }^{120}$ All that is necessary is to recognize that neither the text of the Constitution nor the intent of the framers support a position that prohibits Congress from using certain of its constitutional powers to enfranchise the District.

${ }^{120}$ Indeed, such a determination would require a court to rule that this is, in fact, the case. The few courts, however, which have considered the issue, even indirectly, have shown an unwillingness to rule this way. See, e.g., Hepburn v. Ellzey, 6 U.S. (2 Cranch) 444, 452 (1804) (remarking that "state," when used in the Constitution to refer to the "legislative and executive departments" is only used in the "limited sense" to refer to a "member of the union"); United States v. Cohen, 733 F.2d 128 (D.C. Cir. 1984) (en banc) (denying an equal protection challenge based on dissimilar treatment between federal criminal defendants being tried in the District of Columbia and those tried in the other states). Cohen is a good example of a recent case which readily accepts the current lack of representation for the District and the results it causes.

The reluctance of the judiciary to hold that the District must be considered a "state" for representation purposes is understandable. Such an issue may appropriately be considered a "political question" more suited for congressional resolution. Although the "republican form of government" clause is the most well established subject of the doctrine of non-justiciability of "political questions," other issues may also be covered by the doctrine. See Baker v. Carr, 369 U.S. 186 (1962) (outlining standards for determining what should be considered a "political question" and nonjusticiable). Given the complex facts of the D.C. representation issue and the lack of a readily implementable judicial remedy, it could easily be considered a "political question" more suited to congressional, rather than judicial resolution, particularly since Congress has usually made the determination whether or not to treat the District as a "state" in the past. What is important, however, is not trying to determine whether this should or should not be a "political question," but rather to note that the courts may consider it as such. Thus, it is entirely possible that only Congress can correct the situation and that the courts should and will give congressional decisions in this area considerable deference. See also infra notes 174-78 and accompanying text (discussing why Congress may be the more appropriate body from an institutional competence standpoint). 
To summarize, when we examine the constitutional passages granting congressional representation to the states using traditional tools of interpretation, it appears that "state" is a flexible concept which does not necessarily have to exclude permanently the District. Indeed, the District has been treated as a "state" for many purposes. The Supreme Court has held that whether the District is to be considered a "state" will depend on the particular circumstances involved. In the case of congressional representation, protection of the fundamental right to vote and preservation of the kind of republican, democratic system intended by the framers, are powerful reasons to favor an interpretation which would either consider the District a "state" for purposes of representation, or at least leave the question open to legislative action. Only a very strict, very strained reading of the constitutional clauses would forever prohibit legislative enfranchisement of the District. Such a reading is not only out of touch with our traditional means of interpreting the Constitution, but given the fundamental rights involved in this case, it is completely out of place.

2. Congress Has the Constitutional Power to Pass Legislation Treating the District as a State for Purposes of Congressional Representation

Given the ambiguity and flexibility in the concept of a state, congressional action treating the District as a state for purposes of representation should pass constitutional muster. The constitutionality of such action does not have to depend on some ill-defined congressional power to clarify ambiguous constitutional provisions involving "political questions" or to correct fundamental injustices in our system; rather, the Constitution explicitly provides Congress with ample power to undertake such action.

\section{a. Exclusive Legislation}

Perhaps the clearest indication that Congress should have the power to correct District disenfranchisement is contained in the exclusive legislation clause which grants Congress power to exercise "exclusive Legislation in all Cases whatsoever" in the District. ${ }^{121}$ Congress's powers over the District are not limited to simply those powers that a state legislature might have over a state; they are

121 See U.S. CoNST. art. I, § 8, cl. 17. 
much greater. The federal courts have emphasized the magnitude of this power on numerous occasions. "The object of the grant of exclusive legislation over the district was, therefore, national in the highest sense. ... In the same article which granted the powers of exclusive legislation ... are conferred all the other great powers which make the nation." 122 It has been held that Congress can "provide for the general welfare of citizens within the District of Columbia by any and every act of legislation which it may deem conducive to that end." 123 Perhaps even more on point, the plurality opinion in National Mutual Insurance Co. v. Tidewater Transfer Co. ${ }^{124}$ used the exclusive legislation clause as a rationale to justify the constitutionality of a congressional act bestowing federal diversity jurisdiction on suits involving citizens of the District, in spite of article III which limits such jurisdiction to suits involving citizens of different "states." In effect, the Court allowed Congress, under the exclusive legislation clause, to treat the article III reference to "states" as including the District for purposes of federal jurisdiction.

The parallel between National Mutual and potential legislation enfranchising the District cannot be ignored. If the exclusive legislation clause allows Congress to treat the District as a "state" for purposes of article III and federal jurisdiction, then it should also allow Congress to treat the District as a "state" for purposes of article $I$, the seventeenth amendment, and congressional represenation. Such a result would certainly be consistent with the constitutionally enacted policy of allowing Congress to do whatever it deems necessary to protect the general welfare of D.C. residents. Indeed, if Congress is deprived of this power, the states will be able to thwart attempts to provide voting rights to the District, as they did by failing to ratify the 1978 proposed constitutional amendment. It appears completely inconsistent with the scope of national power expressed in the exclusive legislation clause for the national legislature to be unable to provide basic rights for District citizens (citizens directly entrusted to congressional care under the Constitution) because of the politically motivated opposition of the states.

122 O'Donoghue v. United States, 289 U.S. 516, 539-40 (1933). Presumably, these "great powers" include the power to admit states to the union and the power to regulate elections. The role of each of these powers in supporting Congress's authority to treat the District as a "state" for purposes of representation is discussed further below. See infra notes 184-189 and accompanying text.

123 Neild v. District of Columbia, 110 F.2d 246, 250-51 (D.C. Cir. 1940).

124387 U.S. 582 (1949). 


\section{b. The Civil War Amendments}

Certainly the exclusive legislation clause has limits, particularly when the legislation affects not just the District, but the rest of the nation as well. Although the exclusive legislation clause appears to give Congress sufficient power to treat the District as a "state" for purposes of representation, it may be argued that such legislation exceeds the clause's limitations because it unduly infringes on states' rights. By treating the District as a "state," Congress would slightly reduce the power every other state has in Congress. In addition, this legislation would implement a proposal that the states have already rejected in their failure to ratify the 1978 Voting Rights Amendment. To some extent, these objections may be countered within the framework of the exclusive legislation clause: case law (particularly National Mutual) suggests that Congress can pass legislation to protect District residents in its capacity as a national legislature, even if it does adversely impact the states (particularly if the "necessary and proper" clause is used in aid of the exclusive legislation clause). However, even stronger constitutional support for congressional action of this kind may be found in the Civil War amendments, particularly the fourteenth and fifteenth.

\section{i. Intent of the Civil War Amendments}

One very important aspect of the Civil War was that it vastly increased national power at the expense of the states; it transformed the United States from a federation of independent states into a single nation, where states are just political subdivisions subordinated to a national authority. ${ }^{125}$ While the South fought for "states' rights," the North fought for national power and "individual rights," most specifically the right of individuals to be free from slavery. The victory of the North's ideals is clearly reflected in the thirteenth, fourteenth, and fifteenth amendments, each of which explicitly gives Congress the right to protect the newly proclaimed individual rights "by appropriate legislation," 126 even if it interferes with what might have previously been viewed as states' rights. "Those Amendments were specifically designed as an expansion of

125 This analysis is also applicable in interpreting the constitutional clauses granting representation to "states." See supra notes 67-120 and accompanying text. Clearly, after the Civil War, "state" no longer meant what it once did, nor did the "states" have the power and sovereignty which they did in 1787.

${ }^{126}$ See U.S. CoNST. amend. XIII, § 2; id. amend. XIV, § 5; id. amend. XV, § 2. 
federal power and an intrusion on state sovereignty. ${ }^{n 127}$ The message is clear: states no longer have rights, people do. Use of the enforcement clauses of the fourteenth and fifteenth amendments to grant a fundamental political right to individuals in the District of Columbia by national legislative action, irrespective of state opposition, is entirely consistent with the aforementioned nationalizing intent. ${ }^{128}$

ii. Due Process, Equal Protection, and the Prohibition on Racial Discrimination in Voting

The fact that legislation might be consistent with the general intent of the Civil War amendments is not, in itself, sufficient grounds for determining that the legislation is constitutional; ${ }^{129}$ the legislation must also be in accordance with the actual amendments. Careful analysis reveals that, indeed, disenfranchisement of District residents can reasonably be considered a violation of due process, equal protection, and the prohibition of racial discrimination concerning the right to vote. This is particularly true given Congress's expanded ability under the enforcement clauses to pass "appropriate" legislation attacking practices that are not judicially adjudged to be violative of the Constitution. ${ }^{130}$

The Constitution guarantees "due process of law" to all United States citizens in the fifth and fourteenth amendments. ${ }^{131}$ The fourteenth amendment also guarantees "equal protection."132 Even though several cases, relying on the language of section one, have stated that the duty of equal protection expressed in the fourteenth amendment only applies to the states, ${ }^{133}$ courts have

${ }^{127}$ City of Rome v. United States, 446 U.S. 156, 179 (1980).

128 The need for national legislative action, as opposed to the amendment procedure, was made clear by the failure of the 1978 proposed constitutional amendment. Allowing the states to thwart a national attempt to expand voting rights, as happened with the amendment, is directly contrary to the intent of the Civil War amendments.

${ }^{129}$ Although, the fact that the legislation is consistent with the intent of these amendments might well be considered strong supporting evidence that the legislation should be considered constitutional solely on the basis of the exclusive legislation clause.

${ }^{130}$ See infra notes 154-82 and accompanying text (discussing Congress's power, under the enforcement clauses, to identify and remedy violations of the fourteenth and fifteenth amendments).

131 See U.S. CONST. amend. V; id. amend. XIV, § 1.

132 See U.S. CoNST, amend. XIV, § 1.

${ }^{133}$ See District of Columbia v. Carter, 409 U.S. 418,424 (1973) ("the District of 
interpreted the Constitution in such a way that the duty of equal protection also applies to the federal government (and hence, to the District of Columbia) through the fifth amendment. ${ }^{134}$ Thus, the Constitution provides "overlapping guarantees" of due process and equal protection to all citizens of the United States. ${ }^{135}$ The question then becomes, can the fact that U.S. citizens living in the District of Columbia are deprived of the right to vote for congressional representatives be considered a violation of due process and/ or equal protection? It is essential to note that the question is not whether the status quo in the District constitutes a situation which can and should be ruled a violation under current case law by the courts, but rather, could Congress rationally consider the situation as being contrary to the constitutional ideals of due process and equal protection. ${ }^{136}$ In fact, as argued below, it could, and thus, Congress can correct the violation by appropriate legislationlegislation granting representation to the District.

The "fundamental rights" strand of equal protection and due process analysis has long recognized the importance of the right to

Columbia is not a 'state' within the meaning of the Fourteenth Amendment"); Bolling v. Sharpe, 347 U.S. 497, 499 (1954) ("the Fourteenth Amendment . . . applies only to the states").

134 See, e.g., Johnson v. Robison, 415 U.S. 361, 366 n.4 (1974) ("if a classification would be invalid under the Equal Protection Clause of the Fourteenth Amendment, it is also inconsistent with the due process requirement of the Fifth Amendment"); Cruz v. Hauck, 404 U.S. 59, 62 n.10 (1971) ("Although no explicit equal protection clause is directed by the Constitution against the Federal Government the concept of equal protection of the laws is incorporated into the Due Process Clause of the Fifth Amendment."); Bolling v. Sharpe, 347 U.S. 497, 499 (1954) ("[T]he concepts of equal protection and due process, both stemming from our American ideal of fairness, are not mutually exclusive."). The interrelationship between the fifth and fourteenth amendments, particularly with regard to congressional remedial powers, is discussed in more detail below. See infra note 156. At this point in the discussion, all that is important is that U.S. citizens, whether they live in the District or in the other states, are entitled to essentially the same legal rights of "due process" and "equal protection."

135 In fact, a strong argument may be made that if District residents are being deprived of due process and equal protection, then citizens residing outside the District are being deprived as well. If a citizen outside the District is deprived of an ally because a like-minded citizen within the District cannot vote (or exercise some other fundamental right), then she is arguably being denied due process and equal protection as much as the citizen within the District. Also, if two citizens are unconstitutionally being treated unequally, then arguably neither is receiving equal protection. Thus, even if we accept that the fourteenth amendment does not apply within the District, when District residents are deprived of due process and equal protection, the fourteenth and fifth amendments are still being violated.

136 See infra notes 154-84 and accompanying text (discussing congressional power to identify and remedy equal protection and due process violations). 
vote. The Court has consistently reaffirmed the position that equal protection will require strict judicial scrutiny where a governmental policy impinges upon a "fundamental" ... right ... explicitly or implicitly guaranteed by the Constitution. ${ }^{n 137}$ What qualifies as a "fundamental right" may vary. "[T]he Equal Protection Clause is not shackled to the political theory of a particular era. . . . Notions of what constitutes equal treatment for purposes of the Equal Protection Clause do change. ${ }^{\text {138 }}$ Nonetheless, in some form or another, voting has, for more than a century, been regarded as a fundamental right. ${ }^{139}$

Perhaps the strongest statement of why voting should be considered a fundamental right is contained in Reynolds $v$. Sims, ${ }^{140}$ often regarded as the first case announcing the one-person, onevote principle.

[T] he right of suffrage is a fundamental matter in a free and democratic society ... since the right to exercise the franchise in a free and unimpaired manner is preservative of other basic civil and political rights.... [T] and unimpaired fashion is a bedrock of our political system. ${ }^{141}$

Given our representative system of government and lawmaking, any notion of "due process" would seem to require a role in the political process, absent, of course, a compelling state interest to the contrary. Similarly, absent such a compelling interest, equal protection requires that citizens be treated equally with regard to the franchise. ${ }^{142}$

While many persuasive arguments can be made that the previously cited precedents and principles should not apply to the District, and thus, that a court should not find the inability of District residents to vote for congressional representatives to be a violation of due process or equal protection, ${ }^{143}$ the principles

${ }^{137}$ San Antonio Indep. School Dist. v. Rodriguez, 411 U.S. 1, 33-34 (1973).

${ }^{138}$ Harper v. Virginia Bd. of Elections, 383 U.S. 663, 669 (1966).

139 See, e.g., Yick Wo v. Hopkins, 118 U.S. 356, 370 (1886) (stating that the "political franchise of voting" is a "fundamental political right, because [it is] preservative of all rights").

140377 U.S. 533 (1964).

141 Id. at 561-62.

142 See, e.g., Kramer v. Union Free School Dist. No. 15., 395 U.S. 621, 630-31, 633 (1969) (holding unconstitutional a restriction on the right to vote in school district elections to those "primarily interested" since the exclusion was not necessary to promote a compelling state interest).

143 For instance, it may be argued that congressional representation is not required where the Constitution has intended that it not exist. While the Constitu- 
guiding the fundamental rights strand of analysis may be usefully applied to the District. On a very basic substantive level, when several hundred thousand persons living in a particular geographic entity under the direct control of the federal government are deprived of a fundamental right, the right to vote for congressional representatives, these citizens are not receiving "due process of law." In reality, they are systematically excluded from the "process." Likewise; when these citizens are deprived of a fundamental right granted to virtually all other American citizens simply because of where they reside, they are not receiving "equal protection" of the laws. In fact, denying the District representation may constitute a form of "geographic discrimination." ${ }^{\text {144 }}$

Furthermore, several popular academic theories concerning the proper scope and application of due process and equal protection analysis also suggest that depriving District residents of the franchise should be considered unconstitutional. The "political process" theory, often attributed to the famed Carolene Products footnote $^{145}$ and John Hart Ely, ${ }^{146}$ suggests that the "political

tion seems to envision territories which will not be represented, the situation is much less clear as to what the intent was with respect to the District. See supra notes 108-15 and accompanying text. For a discussion of why the District is not like other territories which are unrepresented but apparently are immune from equal protection challenge, see infra notes 198-200 and accompanying text. Another persuasive argument might be that equal protection analysis has only been applied where the franchise has already been granted; since the District currently has no vote, it is senseless to require that the vote be distributed equally and fairly. Such a point, however, is more a reflection of how far current case law has carried the analysis rather than a binding limitation on how far these principles may be carried by either a court or Congress in attempting to guarantee equal protection.

${ }^{144}$ For a framework discussion analyzing when "geographic discrimination" should constitute an equal protection violation, see Neuman, Territorial Discrimination, Equal Protection and Self-Determination, 135 U. PA. L. REV. 261 (1987). Although Professor Neuman does discuss the problem of the District of Columbia specifically, he presupposes the lack of representation for the District. See id. at 352-71. Even so, some of the conclusions may be relevant to the problem of representation. If it is true that " $[w]$ here Congress adopts a uniform rule in the states, and a different rule in the District . . . normal equal protection principles do apply," $i d$. at 370, then lack of representation, by analogy, may present an equal protection problem. Professor Neuman also argues that a policy of always treating District residents as a suspect class because of their lack of representation would be unworkable. See id. at 355-56. While this may be true, the argument may be turned around. If the lack of representation would ordinarily merit treatment of District residents as a suspect class, and if this cannot take place because it is "unworkable," perhaps the answer lies in providing representation to solve the equal protection dilemma, rather than in altering the standard equal protection principles.

145 See United States v. Carolene Prods. Co., 304 U.S. 144, 153 n.4 (1938) (suggesting that a more rigorous judicial inquiry might be required when actions affect 
process" cannot be relied on as it applies to residents of the District because District residents are a discrete and insular minority (compared to the rest of the U.S. population) completely excluded from direct congressional representation. Since District residents cannot rely on ordinary political processes from which they are systematically excluded, ${ }^{147}$ they are entitled to special protection under the due process and equal protection clauses. Ideally, the "defect" in the political process which results in disenfranchisement should be cured by affirmative government action. Under the "equality of respect" view of equal protection, often attributed to Kenneth Karst ${ }^{148}$ and C. Edwin Baker, ${ }^{149}$ citizens in the District are entitled under the Constitution to be treated with the same concern and respect as all other U.S. citizens. Depriving District residents of a fundamental right basic to American democracy, a right enjoyed by American citizens in the other fifty states, disparages the worth of each and every D.C. citizen, and treats each one as less of a citizen than other U.S. citizens. Under an equality of respect notion, this would clearly violate the Constitution.

In addition to the fourteenth amendment, there is also the fifteenth amendment which states that " $[\mathrm{t}] \mathrm{he}$ right of citizens of the

"discrete and insular minorities" such that "political processes ordinarily to be relied upon" may not produce acceptable results).

${ }^{146}$ See generally J. ELY, DEMOCRACY AND DISTRUST (1980) (arguing for a "representation-reinforcing" approach where heightened scrutiny would be required to protect minorities in situations "where representative government cannot be trusted").

${ }^{147}$ The right to elect congressional representatives must be considered at the root of the political process. Without this right, citizens lack any voice in government and have no one who may be held electorally accountable. See id. at 117 (stating the belief that "unblocking stoppages in the democratic process is what judicial review ought preeminently to be about, and denial of the vote seems the quintessential stoppage"). See also Reynolds v. Sims, 377 U.S. 533 (1964) (discussed supra at notes $140-41$ and accompanying text). Reynolds, as well as other voting rights cases, shows the Court's concern with protecting the vote as an essential part of the political process.

148 See generally Karst, Why Equality Matters, 17 GA. L. REv. 245 (1983) (arguing for an "Equal Citizenship" principle where each individual has a right to be treated by society as an equally respected and participating member); Karst, The Supreme Court, 1976 Term-Foreword: Equal Citizenship Under the Fourteenth Amendment, 91 HARV. L. REv. 1 (1977) (same principle).

149 See generally Baker, Outcome Equality or Equality of Respect: The Substantive Content of Equal Protection, 131 U. PA. L. REV. 933, 934 (1983) [hereinafter Baker, Equality of Respect] (analyzing "the inevitable flaws of outcome equality models and describ [ing] key features of a preferable alternative, the equality of respect model"); Baker, Neutrality, Process and Rationality: Flawed Interpretations of Equal Protection, 58 TEX. L. REV. 1029 (1980) (discussing competing models of equal protection including the equality of respect model). 
United States to vote shall not be denied or abridged by the United States or by any State on account of race." ${ }^{150}$ It is well known that the population of the District is overwhelmingly black; in fact, several prominent individuals have alleged that race has been a major factor in the failure to remedy the problem of District disenfranchisement. ${ }^{151}$ Thus, it is possible that District residents are being deprived of the right to vote for congressional representatives on the basis of race. In fact, in order to justify congressional action, it is not even necessary to show "intent" to discriminate on the basis of race. ${ }^{152}$ There is little doubt that, given the demographic composition of the District, the lack of congressional representation impacts much more heavily on blacks than whites. "Discriminatory impact" may well, in itself, be considered sufficient to prove a congressionally remediable violation of the fifteenth amendment. ${ }^{153}$

\section{iii. Congressional Power Under the Enforcement Clauses}

Even if there are reasons why a court cannot or should not find the disenfranchisement of District residents to be unconstitutional, ${ }^{154}$ a position that disenfranchisement is inconsistent with due process, equal protection, and the prohibition on racial discrimination in voting certainly seems reasonable. Indeed, if Congress is constitutionally permitted to identify situations which are inconsistent with the mandates of the Civil War amendments, this situation provides one instance where such a determination would be

${ }^{150}$ U.S. CoNST. amend. XV, § 1 (emphasis added).

151 See supra note 6.

152 See infra notes $153,171-73$ and accompanying text. Indeed, intent is almost always difficult to prove. In this case it is almost certainly impossible. Theoretically, in order to show that the District has not received the right to vote because of racial considerations, it would be necessary to show improper racial motivation on the part of all those who could enfranchise the District (i.e. Congress, state legislators, etc.).

153 Whether or not "discriminatory impact" in this case actually constitutes a violation becomes unimportant once we realize that the scope of congressional remedial powers, discussed in the next section, allows correction of situations which cause a "discriminatory impact." See infra notes 154-84 and accompanying text; City of Rome v. United States, 446 U.S. 156, 175 (1980) (holding that "under the Fifteenth Amendment, Congress may prohibit voting practices that have only a discriminatory effect").

154 As a practical matter, it is virtually impossible to imagine a court deciding the status quo to be unconstitutional. Doctrinally, this issue may represent a nonjusticiable "political question," particularly since it is unclear what remedy a court could implement that would cure the situation and still not violate the constitutionally mandated balance of powers. See supra note 120. 
sufficiently supported by the facts, constitutional text, precedent, and constitutional theory to survive challenge. Fortunately, under the enforcement clauses of the fourteenth and fifteenth amendments, ${ }^{155}$ and current case law interpreting them, it appears that Congress may not only remedy constitutional violations already noted by the courts, but it may identify and remedy violations using any means which are "appropriate." 156

In both South Carolina v. Katzenbach, ${ }^{157}$ and Katzenbach $v$. Morgan, ${ }^{158}$ the Court upheld provisions of the Voting Rights Act of 1965, even though the provisions may not have been implemented to correct court-identified violations of the fourteenth and fifteenth amendments. In the former case, the Court found that remedies for voting discrimination "which go into effect without any need for prior adjudication ${ } 159$ may be entirely appropriate, legitimate, and permissible under the enforcement clause of the fifteenth amendment. In Morgan, the Court stated that to construe the fourteenth amendment in such a way that

155 "The Congress shall have power to enforce, by appropriate legislation, the provisions of this article." U.S. CoNST. amend XIV, § 5. "The Congress shall have power to enforce this article by appropriate legislation." Id. amend. XV, $\S 2$. Given the almost identical language of these two clauses it is not surprising that the courts have treated them in essentially the same manner.

${ }^{156}$ As discussed earlier, although some cases have said that the fourteenth amendment does not apply in the District, see supra note 133 and accompanying text, due process and equal protection do apply through the fifth amendment. See supro note 134 and accompanying text; see also supra note 135 (suggesting that where District residents are deprived of due process and equal protection, the fourteenth amendment is violated). Although the fourteenth and fifteenth amendments have explicit enforcement clauses, the fifth does not. This, however, does not present much of a problem. Congressional authority to enforce due process and equal protection in the District may be derived from the "exclusive legislation" clause and the "necessary and proper" clause. Certainly if congressional power with in the District is "exclusive," this power cannot be less than the power over the states granted in the Civil War amendments, under which Congress may only pass legislation which is "appropriate" for enforcement. If the legislation were only to affect the District, the exclusive legislation clause would provide sufficient constitutional support. It is where such legislation affects the nation as a whole, and infringes on state domains, (as arguably occurs here), that the enforcement clause of the fourteenth must be invoked. Indeed, Congress has on previous occasions passed nationwide legislation (explicitly including the District) under the enforcement provision of the fourteenth amendment. See Civil Rights Act of 1964, 42 U.S.C. \$ 2000(e) (1982); New York Gaslight Club, Inc. v. Carey, 447 U.S. 54 (1980) (noting that the Civil Rights Act was legitimately passed, at least in part, under $\$ 5$ of the fourteenth amendment); Hazelwood School Dist. v. United States, 433 U.S. 299, 306 n.12 (1977) (same).

157383 U.S. 301 (1966).

158384 U.S. 641 (1966).

159 South Carolina, 983 U.S. at $327-28$. 
would require a judicial determination that the enforcement of the state law precluded by Congress violated the Amendment, as a condition of sustaining the congressional enactment, would ... confine the legislative power ... to the insignificant role of abrogating only those state laws that the judicial branch was prepared to adjudge unconstitutional .... ${ }^{160}$

Because of this, the Court found that its role "is limited to determining whether such legislation is, as required by $\S 5$, appropriate legislation to enforce the Equal Protection Clause."161 The Court summarized its view of the appropriate scope of congressional power by stating that " $\S 5$ is a positive grant of legislative power authorizing Congress to exercise its discretion in determining whether and what legislation is needed to secure the guarantees of the Fourteenth Amendment."162

As to what kind of limits, if any, there are on Congress in its exercise of this power (a concern discussed in the dissent), Justice Brennan, writing for the majority in Morgan, expressed his view, often known as the "ratchet theory", in a footnote: "Congress' power under $\S 5$ is limited to adopting measures to enforce the guarantees of the Amendment; $\S 5$ grants Congress no power to restrict, abrogate, or dilute these guarantees."163 In other words, Congress can use its power to increase fundamental rights and liberties but not to dilute them. The position of the Court in Morgan has been viewed as controversial and has not won sweeping support in either subsequent Court decisions or academic commentary. ${ }^{164}$ Nevertheless, it has never been explicitly overruled and remains, to a significant extent, good law.

In Oregon v. Mitchell, ${ }^{165}$ the Court faced the question whether a statute lowering the voting age to eighteen was valid. In a five to four decision it ruled that it was constitutional as applied to federal elections; a different five to four majority ruled that it was unconstitutional as applied to state elections. Although controversial, the decision provides substantial support for congressional authority to both identify and remedy equal protection violations. Four Justices concluded that under the fourteenth amendment, and under the interpretation of it offered in Morgan, Congress could "undertake

\footnotetext{
${ }^{160}$ Morgan, 384 U.S. at 648-49 (footnote omitted).

161 Id. at $649-50$.

162 Id. at 651 .

163 Id. at 651 n.10.

164 See infra notes $165-84$ and accompanying text.

165400 U.S. 112 (1970).
} 
an investigation" into whether discrimination existed, "make its own determination on the matter," and "remove the discrimination by appropriate means." ${ }^{\text {I66 }}$ In this particular case, "Congress might well conclude that a reduction in the voting age from 21 to 18 was needed in the interest of equal protection." 167 The "swing opinion" in this case, that of Justice Black, was based on Congress's power to regulate national elections, ${ }^{168}$ and on the view that the fourteenth amendment was primarily concerned with racial discrimination. ${ }^{169}$ Even this opinion, however, showed some support for the idea that Congress can identify as well as remedy equal protection violations: "In enacting the 18-year-old vote provisions ... Congress made no legislative findings that the 21year-old vote requirement was used by the States to disenfranchise voters on account of race. ${ }^{n 170}$ Presumably, if it had, the entire act would have been upheld. Thus, a majority of the Court in Mitchell did indeed recognize a broad role for Congress in dealing with equal protection violations.

The decision in City of Rome v. United States ${ }^{171}$ also supports broad congressional power under the post-Civil War amendments. In that case, the Court upheld a portion of the Voting Rights Act of

${ }^{166} I d$. at 248 (Brennan, White \& Marshall J., concurring in part and dissenting in part). Although Justice Douglas wrote a separate opinion, he largely concurred in both the conclusions and reasoning of Justices Brennan, White, and Marshall. See id. at 135, 141-44 (Douglas, J., concurring in part and dissenting in part).

${ }^{167} \mathrm{Id}$. at 141 (Douglas, $\mathrm{J}$., concurring in part and dissenting in part).

168 See id. at 126-30; see also infra notes 188-91 and accompanying text (discussing this power and Justice Black's view of it in Mitchell).

${ }^{169}$ See Mitchell 400 U.S. at 126-30. This view is not supported, however, by either the text of the fourteenth amendment or other Supreme Court opinions which have readily applied fourteenth amendment analysis to a wide variety of forms of discrimination. These include discrimination against particular classes of people, see, e.g. Craig v. Boren, 429 U.S. 190 (1976) (invalidating, on equal protection grounds, a statutory scheme which discriminated on the basis of sex); Graham v. Richardson, 403 U.S. 365 (1971) (striking down, on equal protection grounds, discrimination against aliens); Yick Wo v. Hopkins, 118 U.S. 356 (1886) (striking down, on equal protection grounds, discrimination against Chinese individuals), and discrimination which impinges on fundamental rights, see, e.g., Shapiro v. Thompson, 394 U.S. 618 (1969) (invalidating, on equal protection grounds, durational residence requirements for welfare benefits which were held to unduly burden the right of interstate migration); Williams v. Rhodes, 393 U.S. 23 (1968) (striking down, on equal protection and first amendment grounds, a state statutory scheme which limited access to the ballot of third party and independent candidates); Harper v. Virginia Bd. of Elections, 383 U.S. 663, 668-69 (1966) (invalidating poll tax, on equal protection grounds, as an impermissible limitation on the right to vote).

170 Mitchell, 400 U.S. at 130.

171446 U.S. 156 (1980). 
1965 as applied to certain electoral changes made in Rome, Georgia, as a proper exercise of congressional power under the enforcement provision of the fifteenth amendment. The Court's holding that "Congress may prohibit practices that in and of themselves do not violate $\S 1$ of the Amendment, so long as the prohibitions attacking racial discrimination in voting are 'appropriate"172 suggests an expansive role for Congress in giving actual meaning to voting rights under the substantive provisions of the Civil War amendments. Furthermore, the Court's holding that "even if $\S 1$ of the [Fifteenth] Amendment prohibits only purposeful discrimination, the prior decisions of this Court foreclose any argument that Congress may not, pursuant to $\S 2$, outlaw voting practices that are discriminatory in effect ${ }^{n 173}$ bears particular relevance to the problem of D.C. representation, since under this rationale Congress could pass legislation to correct the racially discriminatory impact of District disenfranchisement.

While case law supports a congressional role in identifying equal protection violations, ${ }^{174}$ the exact limits of this role are far from clear and have generated extensive academic commentary. ${ }^{175}$ Many of the approaches attempt to take advantage of Congress's institutional competence. One application of this theory involves allowing Congress to have some power to "draw lines" and accommodate competing interests as long as it follows the Court's "value

172 Id. at 177.

173 Id. at 173 (footnote omitted).

174 Some Justices have insisted that Congress does not and should not have the power to determine whether a particular situation constitutes a violation of equal protection and have, in fact, read the majority opinions as upholding this theory. See, e.g, id. at 221 (Rehnquist, J., dissenting) (arguing that the majority's decision requires state and local governments and the judiciary to cede more of their power to the federal government than the Constitution envisions); Mitchell, 400 U.S. at 293, 296 (Stewart, J., concurring in part and dissenting in part) (arguing that the Constitution does not confer such broad powers on Congress). The language of the cases, particularly Morgan, does not seem to support this. It seems much more reasonable to read the cases as saying that "at least in some circumstances-where Congress and the Court disagree about the meaning of the Fourteenth Amendment, the Court will defer to Congress' version." Burt, Miranda and Title II: A Morganatic Marriage, 1969 SUP. CT. REV. 81, 83-84.

175 Most of the commentary is directed at section five of the fourteenth amendment. Presumably, much of what is said is also applicable to section two of the fifteenth amendment. Even if it is not, however, cases such as City of Rome make the situation with respect to the fifteenth amendment clearer than that with respect to the fourteenth: Congress clearly can pass legislation attacking practices which have a discriminatory impact, even if they are not adjudged to violate $\$ 1$ of the fifteenth amendment. 
preferences" and only works "'around the edges' of the Court's proclaimed doctrine. ${ }^{n 176}$ This approach takes advantage of Congress's ability to work compromises and draw clear-cut statutory lines in areas in which a court would find it difficult to arrive at a principled approach. Applied to the problem of District disenfranchisement, this approach would seem to favor congressional ability to define the District as a "state" for purposes of representation. Such action, by remedying discrimination and disenfranchisement, would be consistent with the Court's value preferences (as expressed in the various voting rights cases) and would allow Congress to make a clear-cut decision where a court might have trouble. ${ }^{177}$

Another application of the institutional competence idea would require congressional action to be justified by its superior capacity to find and appraise facts, since Congress is presumably better at this than the courts. ${ }^{178}$ The problem with this approach, though, is that finding and appraising facts is inherently intertwined with value choices. In the case of District disenfranchisement, there certainly are relevant facts which Congress can and should investigate, particularly with regard to the impact of disenfranchisement on the District. In order to determine whether District residents are being deprived of equal protection and due process, it would be useful to determine what they are actually being deprived of (besides the right to vote). These facts could be used to justify congressional action. Nevertheless, legislation enfranchising the District would also involve value choices as well as the relevant facts which Congress has found and appraised. In fact, the simple lack of a right to vote (a fact which needs no finding) should be, in itself, enough to justify congressional action. Thus, although the "factfinding" approach to the enforcement provision would permit

${ }^{176}$ Burt, supra note 174 , at 121.

177 This "trouble" is evidenced by the Court's reluctance to declare a clear-cut line as to when the District is to be considered a "state" and when it is not. See supra note 100 and accompanying text.

${ }^{178}$ See Cox, The Supreme Courh 1965 Term-Foreword: Constitutional Adjudication and the Promotion of Human Rights, 80 HARv. L. REv. 91, 107 (1966); Cox, The Role of Congress in Constitutional Determinations, 40 U. CnN. L. REV. 199, 260 (1971). The view is supported by the fact that the Court has, on several occasions, explicitly recognized a predominant fact-finding role for Congress in equal protection cases. See, e.g., City of Richmond v.J. A. Croson Co., 488 U.S. 469, 500 (1989) (acknowledging that courts should defer to legislative fact-finding); Mitchell, 400 U.S. at 247-48 (Brennan, White \& Marshall, JJ., dissenting in part and concurring in part) (noting that the courts are "an inappropriate forum for the determination of complex factual questions"). 
congressional action, it does not seem particularly applicable to this problem.

Another approach to section five of the fourteenth amendment argues for a liberty-federalism differentiation that "distinguish[es] the relative capacity of Congress to draw the lines between national and state power from the courts' sensitivity to the rights of racial, religious, and political minorities." 179 It is not entirely clear what this approach would suggest with regard to the problem of District nonrepresentation. On the one hand, this theory suggests that a congressional judgment involving a "liberty" issue which would be unconstitutional if made by a state, would also be unconstitutional if made by Congress. Certainly, a state cannot give itself congressional representation; then again, it would never have to. ${ }^{180}$ This part of the theory aims to prevent Congress from "rejecting a judicial interpretation of the due process or equal protection clauses." 181 Yet, congressional legislation enfranchising the District would not reject any such judicial interpretations. Furthermore, this problem is primarily federal in nature, involving federal structure that Congress, under the "liberty-federalism" distinction, should have the authority to solve without state interference. Indeed, the only reason why the exclusive legislation clause might not be sufficient authority for legislation treating the District of Columbia as a "state" is due to the extent that such legislation would impact on the states. Thus, although the "liberty-federalism" distinction does not clearly apply to this problem, it easily could be argued that the theory supports congressional action.

One final approach to section five is an outgrowth of the "equality of respect" view. ${ }^{182}$ This view suggests that "[a] selfdefining, democratic polity should be permitted to pursue or promote a more extensive equality than that which is required as a prerequisite to legitimate governance." 183 This view appears to come closest to Justice Brennan's ratchet theory: it would permit policies that pursue an enhanced equality while prohibiting those that reduce equality below an abstract, judicially defined minimum. ${ }^{184}$ Glearly, legislation enfranchising the District of Colum-

179 Cohen, Congressional Power to Interpret Due Process and Equal Protection, 27 STAN. L. REV. 603, 613 (1975).

${ }^{180}$ This fact makes the liberty-federalism distinction seem rather inapplicable when applied to the problem of the District of Columbia.

181 Cohen, supra note 179 , at 614 .

182 See supra notes $148-49$ and accompanying text.

183 Baker, Equality of Respect, supra note 149, at 989.

184 At least some of the other theories concerning the enforcement clause of the 
bia would place its residents on a more equal footing with other American citizens, thereby providing a "more extensive equality." Under the equality of respect model, Congress unquestionably should have the power to correct District disenfranchisement.

In conclusion, Congress ought to, and probably does, have the power to identify D.C. disenfranchisement as a violation of due process and equal protection. Mitchell and even more clearly, Morgan, support a congressional role in situations such as this. Brennan's ratchet theory (which, unlike other "academic" approaches, is grounded clearly in a Supreme Court opinion) would be well served by action granting voting rights to District residents. In addition, much of the academic commentary, particularly the "equality of respect" view, supports this outcome. Congress can also implicate the fifteenth amendment by taking note of the racially discriminatory impact of this problem on voting. Therefore, under the enforcement clauses of the fourteenth and fifteenth amendments, Congress can remedy "by appropriate legislation" the current lack of congressional representation for the District of Columbia. This legislation would take advantage of the flexibility of the term "state" (and the lack of a constitutionally mandated definition of the term) and treat the District as a "state" for purposes of representation. This result is not only constitutional, but it is also entirely consistent with the spirit of the post-Civil War amendments (which give the federal government a central role in protecting individual rights and promoting equality), and takes advantage of their nationalizing effect.

\section{c. Other Constitutional Support: The Power to Admit New States and the} Power to Regulate National Elections

In addition to the exclusive legislation clause and the Civil War Amendments, two other constitutional provisions granting power to Congress could reasonably be interpreted as permitting, or at least supporting, congressional action to enfranchise the District. Prime among the powers granted to Congress is the power to admit new states to the Union. ${ }^{185}$ Over the past two hundred years, Con-

fourteenth amendment also aim at an "intellectually defensible argument" which achieves much the same result as the ratchet theory: giving Congress "wide power to enlarge due process and equal protection but ... [no] power to dilute them." Cohen, supra note 179 , at 614 . In this case, the equality of respect notion comes closest to achieving this aim.

${ }^{185}$ See U.S. CONST. art. IV, § 3. 
gress has admitted many new states to the Union, often through simple legislation. ${ }^{186}$ The admission clause of the Constitution gives Congress wide-ranging powers. Simply by statute, Congress can grant all the benefits of statehood to a particular geographic entity; it may define statehood in any manner it pleases. ${ }^{187}$ It stands to reason that since Congress can define a state for purposes of admission, it should also be able to define what a state is for purposes of representation. If Congress can confer all the benefits of statehood on any particular entity by simple legislation, it should not be surprising that it also has the more limited power to confer one of the benefits of statehood (congressional representation) on an entity which is already part of the Union and "state-like" in virtually all significant respects.

Further constitutional support for congressional power in this area may be found in article one, section four, which empowers Congress to make laws respecting the election of senators and representatives to Congress. ${ }^{188}$ It is clear that the framers intended the new nation to have "the ultimate power to rule itself and to fill its offices under its own laws." 189 This power has been held to include the power to determine "the qualifications of voters" and to "lay out or alter the boundaries of the congressional districts. ${ }^{190}$ Given the extensive congressional power over how its members are chosen, Congress should also have the power to "qualify," in effect, citizens of the District to vote for congressional representatives. Because congressional power over voter qualifications is subject to other constitutional constraints, ${ }^{191}$ this argument in itself may not be completely persuasive. When combined with the constitutional provisions previously discussed, however, Congress's power to determine how its own offices are filled suggests that any doubt should be resolved in favor of a conclusion that Congress may legislatively enfranchise the District of Columbia.

186 See S. MARKMAN, supra note 10, at 33 (describing the various ways in which states have been admitted to the Union).

${ }^{187}$ See supra notes 73-75 and accompanying text.

188 See U.S. CONST. art. I, § 4 ("The Times, Places and Manner of holding Elections for Senators and Representatives, shall be prescribed in each State . . . but the Congress may at any time by Law make or alter such Regulations . . . ."). This power formed the basis of Justice Black's opinion in Mitchell. See supra notes 167-69 and accompanying text.

${ }^{189}$ Oregon v. Mitchell, 400 U.S. 112, 123 (1970).

$190 \mathrm{Id}$. at 121.

191 These constraints include the requirements that each state have two senators and that representatives be apportioned on the basis of population. 
It appears, therefore, that according to the text, intent, and case law interpretation, Congress has the power under several constitutional provisions to confer upon D.G. citizens the right to vote for congressional representatives, particularly where all that is necessary to accomplish this is the passage of legislation defining the District as a "state" for purposes of representation.

\section{Arguments Against the Legislative Solution-Why \\ They Are Unpersuasive}

Several arguments against the legislative solution remain to be addressed. The first argument points to the constitutional provision that "no State, without its Consent, shall be deprived of its equal Suffrage in the Senate." 192 A number of scholars maintain that "to give equal suffrage to nonstates without unanimous consent is to violate Article V."193 This reading, however, is contrary to the actual text of the Constitution and to the intent of the framers. The plain language of this provision only guarantees that all states (and presumably, entities that are to be treated as states for purposes of representation) will have an equal vote in the Senate. Furthermore, "the history of the proviso indicates that its purpose was to ensure equality of the states in the Senate, and not to prevent the 'dilution' of their votes." 194 Adding two senators from a new state dilutes the votes of existing states but clearly does not disturb the equality of the existing states. ${ }^{195}$ The same effect, and the same lack of constitutional problems, follows from adding an entity that is sufficiently state-like to be legislatively treated as a state.

Another argument holding little merit asserts that the District should not have representation because a very large percentage of District citizens are employed by the federal government and thus, "[i]ts representatives in Congress would not only speak for a single interest group, they would vastly overrepresent a narrow constituen-

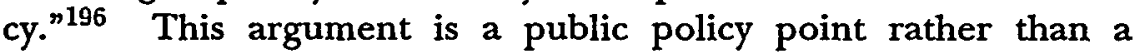
constitutional argument, and is bad public policy at that. The

192 U.S. CONST. art. V.

${ }^{193}$ J. BEST, supra note 17, at 49. See also S. MARKMAN, supra note 10, at 29-31 (arguing for the same position).

194 Raven-Hansen, supra note 11, at 189.

195 If it did, the addition of each new state to the Union over the past two hundred years would have to be considered unconstitutional. See S. MARKMAN, supra note 10 , at 29.

$196 \mathrm{~J}$. BEST, supra note 17 , at 74. 
argument ignores both that many citizens of the District are not federal employees, ${ }^{197}$ and that even those who are have diverse interests across a broad spectrum of issues. It vastly oversimplifies politics to say that everyone who works for the same employer has interests that are sufficiently similar for them to be considered a "single interest group." Furthermore, although obvious, it is still worth noting that federall employees are citizens too, and are entitled to have their interests represented in Congress. In fact, if one concedes that federal employees constitute a single "narrow constituency," the argument that District congressional representation would overrepresent that constituency may be turned on its head: given the concentration of federal employees in the District, it may well be that the current lack of representation vastly underrepresents this narrow constituency. As a matter of principle, the employment status of a group of citizens should be irrelevant to determinations concerning their political rights.

The next argument against congressional representation for the District of Columbia stems from comparisons of the District of Columbia with other territories and possessions of the United States. ${ }^{198}$ Since the framers conceived of territories without representation, and presumably did not see much of a problem, why should the District be treated any differently? Furthermore, if the District can receive representation without statehood, why not other territories? The problem with this argument, however, is that the District is not like other territories. In American history, there have essentially been only two kinds of territories: those ultimately destined for statehood, such as the Northwest Territories and Alaska, and those ultimately destined for independence, such as the Philippines. ${ }^{199}$ Often, the destiny of the territory is completely in the hands of its residents. ${ }^{200}$ The District obviously cannot be-

197 The issue of what percentage of District residents should be considered employees of the federal government is disputed, but in general, it seems that about one-third are employed directly by the federal government and two-thirds are "employed either directly or indirectly in the business of the federal government." S. MARKMAN, supra note 10 , at 58 . What is clear, however, is that a substantial percentage of residents are not federal employees.

198 See, e.g., id. at 14 (comparing the District of Columbia to Puerto Rico and Guam).

${ }^{199}$ See Raven-Hansen, supra note 11 , at 190 (discussing the difference between incorporated and unincorporated territories).

200 Puerto Rico has had two referenda and a plebiscite concerning what its future status should be. See Colon, The Caribbean, Economist, Sept. 24, 1988, at 6; Phillips, Puerto Ricans Political Status in Limbo Again, USA Today, March 6, 1991, at 7A, col. 1. 
come independent, and it appears it will not be able to become a state. Indeed, if no legislative solution is implemented, the District may not have any available avenue to achieve representative government, denying its residents a choice as to their status. This outcome is certainly not what the framers intended, nor is it a result which should be permitted today. The District is different, and it should be treated differently; legislating representation is a viable option that Congress can and should exercise.

In many areas of legislation, Congress has treated the District as a state. ${ }^{201}$ The Supreme Court has also considered the District to be a state on numerous occasions. ${ }^{202}$ Such an approach often makes sense, since the District is like a state in many ways. It therefore makes both political and constitutional sense for Congress to pass legislation granting the District representation in Congress, thereby treating it as a state for purposes of representation. The ambiguity and flexibility in the clauses providing for congressional representation for the "states" combined with various powers granted to the Congress ensure that such an approach would be constitutional. By maintaining federal exclusive jurisdiction over the seat of the national government, this approach presents a clear advantage to statehood and retrocession. It would appear that simple legislation is the ideal remedy to a complex problem that has been with us for almost two centuries.

\section{CONCLUSION}

The purpose of this Comment has been to present a practical approach to a problem of fundamental justice and fairness which has been receiving increasing national attention. Legislating congressional representation for the District of Columbia is the solution most consistent with our fundamental beliefs and values concerning the District and the nature of our democratic system as a whole. It grants fundamental voting rights and real political power while maintaining the District's unique status as an independent federal city under congressional control. No other solution achieves this result. Much of this Comment has been dedicated to showing that such an approach is constitutional. A fundamental assumption underlying these arguments has been that the Constitution should be interpreted in such a manner as to solve problems

201 See supra note 102 and accompanying text.

202 See supra notes 84-100 and accompanying text. 
involving fundamental rights and the political process, not to create them. Ultimately, it is up to us as to how we wish to read and interpret the Constitution. If some, for political or personal reasons, wish to construe the Constitution as prohibiting a legislative solution to the problem of D.C. representation, certainly arguments exist to support that position. However, if we really wish to treat the citizens of our nation's capital fairly, if we wish to restore to them rights enjoyed by virtually all other American citizens, we can, without much difficulty, construe the Constitution as permitting a legislative solution. Certainly, this interpretation is at least as valid, and probably more so, than the contrary reading. In short, the Constitution should be construed in such a manner as to further the rights and values implicit in it; a reading which contradicts these rights and values and prohibits attempts by a wellmeaning Congress to pass legislation which embodies them should be avoided whenever possible. ${ }^{203}$

The legislative solution also represents a proper exercise of federal and congressional power. An issue such as D.C. representation is one well-suited for resolution by our national legislature. From a balance of power standpoint, solving a problem such as this, which is composed of both complex political problems as well as constitutional issues, is sonething which is well within Congress's institutional competence. Judicial deference to Congress, through a proper exercise of "judicial restraint," allows a solution which takes into account not only the fundamental rights of District residents but also the preferences of other citizens of the nation. Congressional action, since it is undertaken by the directly elected representatives of the nation's citizenry, also has more legitimacy than action by the courts. From a separation of powers standpoint, the legislative solution permits the federal government to handle what is primarily a federal problem (given the exclusive legislation clause) without inappropriate interference by the more provincially oriented state legislatures. Finally, the legislative solution has a very real chance of success, particularly since Congress has already once indicated its desire to settle this problem by providing representation while maintaining the unique independent federal status of the District. By carefully drafting and passing legislation granting

203 We should always keep in mind the words of Chief Justice Marshall, that "it is a constitution we are expounding ... intended to endure for ages to come, and consequently, to be adapted to the various crises of human affairs." MeCulloch v. Maryland, 17 U.S. (4 Wheat.) 316, 407, 415 (1819). 
congressional representation to the District of Columbia, Congress can constitutionally correct a flagrant injustice that has plagued our political system almost since its founding. 


$$
\text { . }
$$

